\title{
Explaining factors related to neck pain and its preventive behaviors in teachers based on the health belief model: A qualitative study
}

\author{
Zohreh Moradi ${ }^{1}$, Sedigheh Sadat Tavafian ${ }^{1 *}$, Seyedeh Somayeh Kazemi ${ }^{2}$ \\ 1. Faculty of Medical Sciences, Tarbiat Modares University, Tehran, Iran \\ 2. Chalous Health Network, Mazandaran Medical Sciences, Chalous, Iran
}

Received: 14 August 2021

Accepted for publication: 22 November 2021

[EPub a head of print-29 November 2021]

Payesh: 2021; 20 (6): 743 - 757

\begin{abstract}
Objective (s): Neck pain is one of the most common musculoskeletal disorders associated with work that leads to important social and economic consequences such as reduced productivity due to absenteeism, early leave and retirement, missed working days, financial loss. Due to medical expenses and poor work ethic due to discomfort when working in the workforce, especially teachers. The aim of this study was to identify and explain the causes of occupational neck pain and promote preventive behaviors based on the health belief model in teachers.

Methods: The was a qualitative study using the directed content analysis approach by telephone interviews with 25 high school teachers working Tehran, Iran, in 2020. Teachers were selected based on simple random sampling. Interview questions were designed based on the constructs of the health belief model and the information was analyzed using MAXQDA software.

Results: Based on the health belief model the following factors including awareness, sensitivity and perceived severity, perceived benefits and barriers, cues to action and self-efficacy emerged as effective factors causing occupational neck pain in teachers.

Conclusion: Teachers expressed a number of reasons for neck pain experiencing. Due to the important role of teachers in educating children, adolescents and young people, their health should be considered a priority.
\end{abstract}

Key words: Hospital Accreditation, Methods, challenges, solution

\footnotetext{
* Corresponding author: Faculty of Medical Sciences, Tarbiat Modares University, Tehran, Iran

E-mail: tavafian@modares.ac.ir
} 


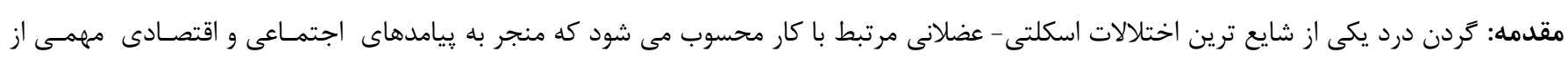

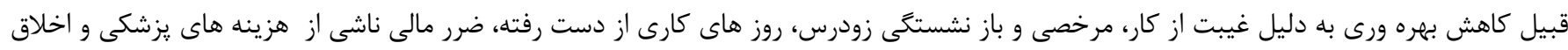

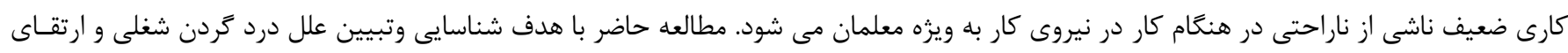

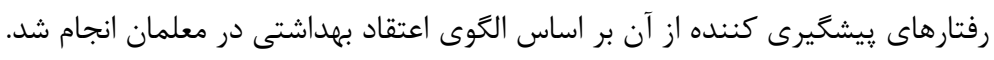

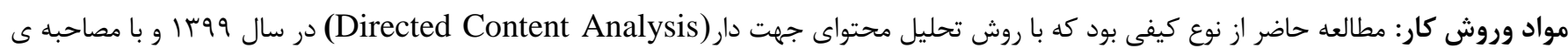

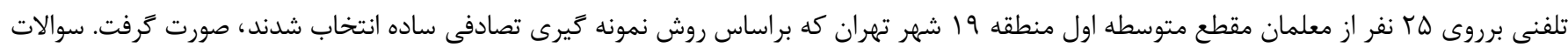

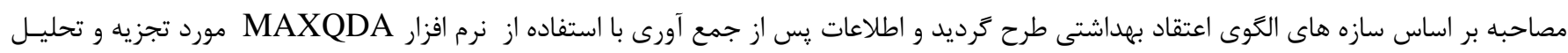
قرار ترفت.

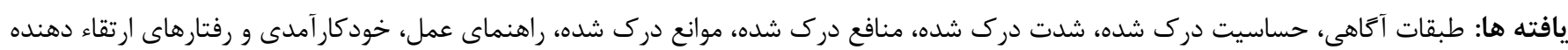

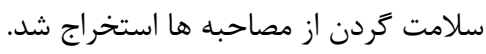

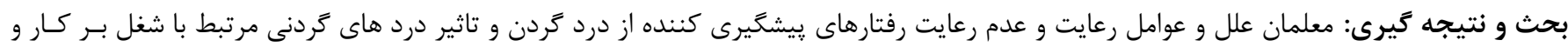

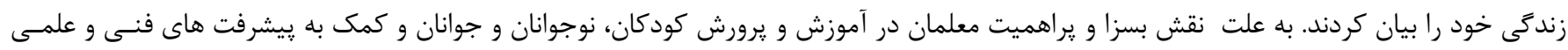

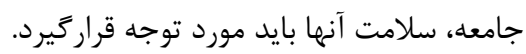

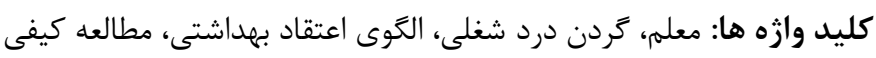

كد اخلاق: IR.MODARES.REC.1399.163 كدكارآزمايى بالينى: كs 
سلامتى سوق مى دهد. دلايل مختلفى براى عـدم انجـام رفتارهـاى

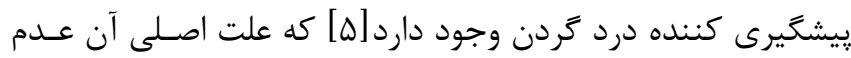

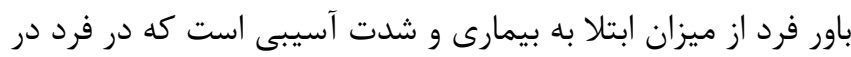

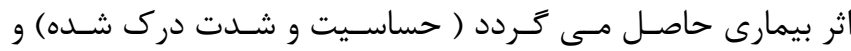
همجنين عدم ارزيابى فرد از منافع و موانع رفتار بهداشتى ( منافع و

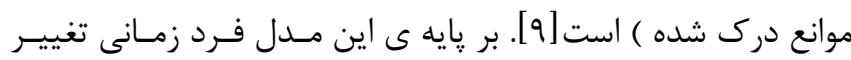

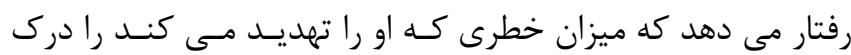

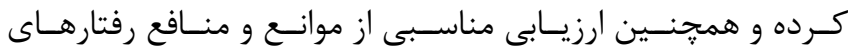
بهداشتى داشته باشد [ [1]. مطالعه كمى در خصوص علل و عوامل موثر بر درد كردن مرتبط بــاــاس

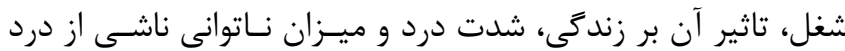

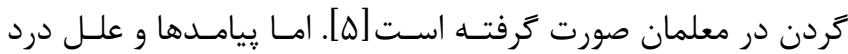

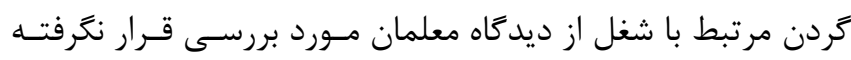

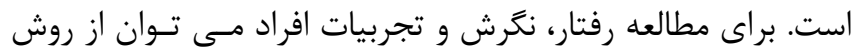

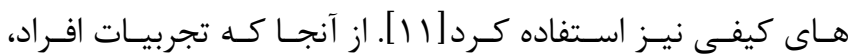

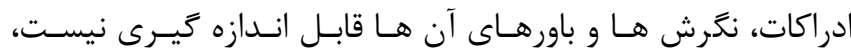
استفاده از روش هاى كيفى مى تواند در اندازه كيرى و درك عميـق

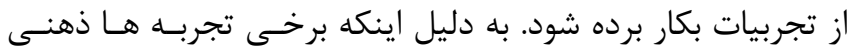

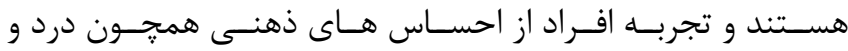

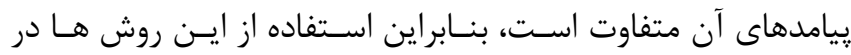
يزوهش هاى مربوط به درك احساس درد و يِيامدهاى آن مى توانسـ

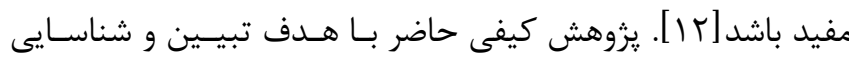
علل درد كردن شغلى و ارتقاى رفتارهاى ييشخَيرى كننده از آن بـر

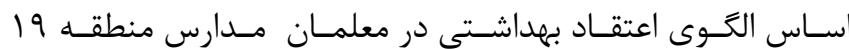

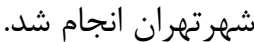

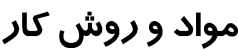

مطالعه ى حاضر، از نوع كيفى بود كه با روش تحليل محتواى جهت

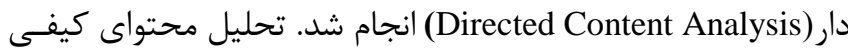
را مى توان روش تحقيقى براى تفسـير ذهنسى محتـوايى داده هـاى متنى از طريق فرآيندهاى طبقه بندى نظام مند، كد بندى، طرائ تراحسى طبقات و زير طبقات و الكَوهاى شناخته شده دانست. در ايـن روش مى توان تعداد زيادى از وازه ها را در كروه هاى محتوايى متراكم تـر

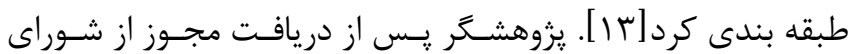

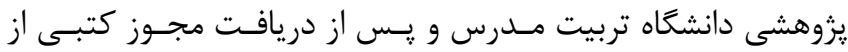

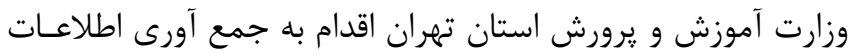

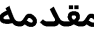

يكى از بزركترين مشكلات بهداشـت شـغلى در جمعيـت شـاغل در

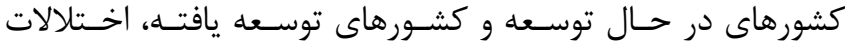
اسكلتى عضلانى ناشى از كار است كه بيشـــرين ميـزان شـكايات از

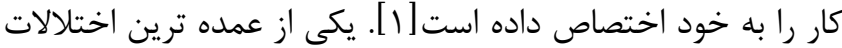
اسكلتى عضلانى مرتبط با كار در جمعيت شاغل به ويزه در معلمان

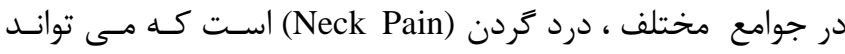

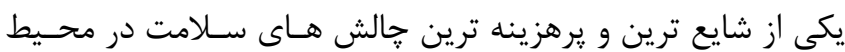

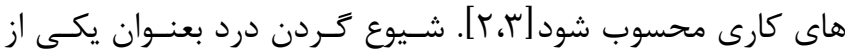

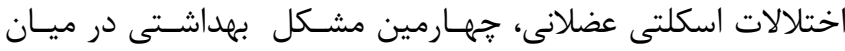

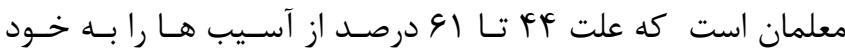

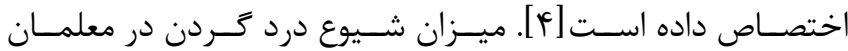

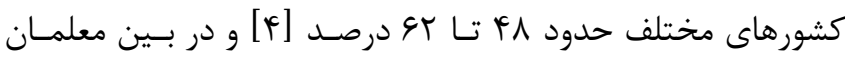

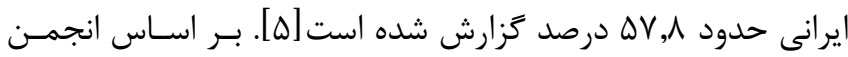

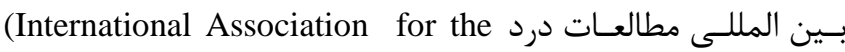
(Cervical Spinal Pain درد ستون فقرات كردن Study of Pain)

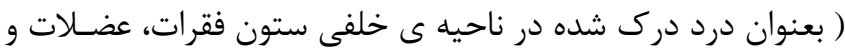

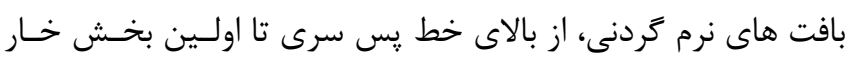

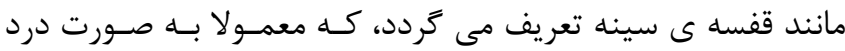

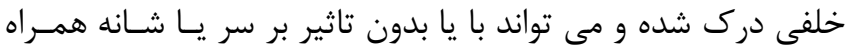

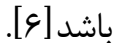
كردن درد تاثير قابل توجهى بر عملكرد اجتماعى، وضعيت سـلامت

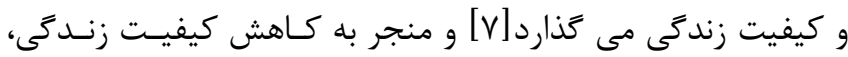

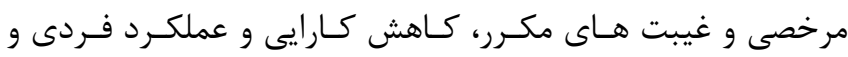

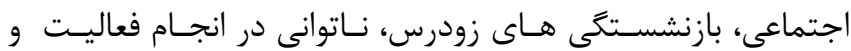

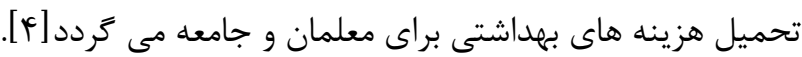

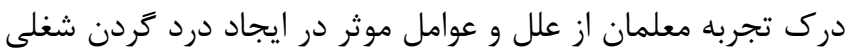

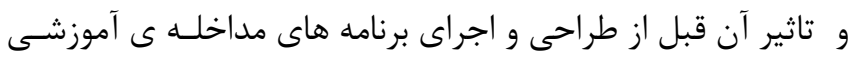

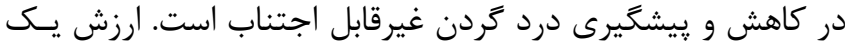
آموزش به اثركذارى آن و تغيير يا ايجاد رفتارهاى سلامتى بسـتـى دانى

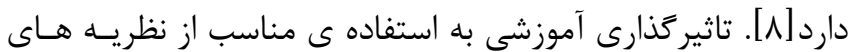

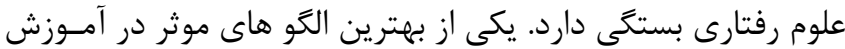
بهداشت در زمينه ى ارتقاء رفتارهاى ييشگيرى كننده الكَوى اعتقاد

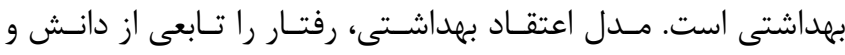

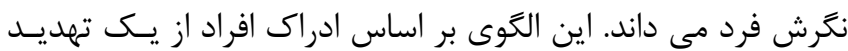

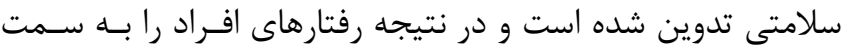


نقش موانع و منافع موجود در انجام رفتارهاى بيشگيرى كننده درد

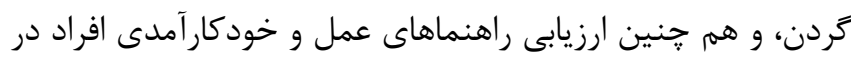

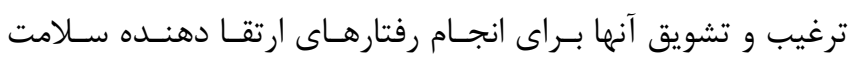

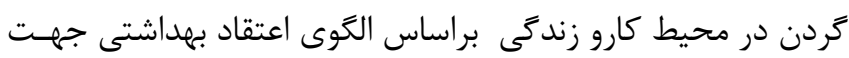
بيشخَيرى و كاهش درد كردن شغلى در معلمان بود برد

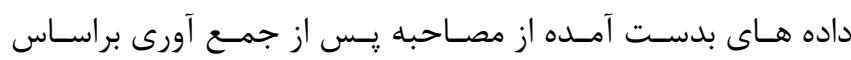

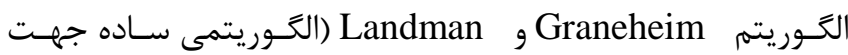
دسته بندى داده هاى كيفى) درتحليـل محتـواى كيفـى تجزيــهـ و

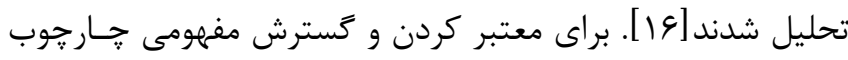

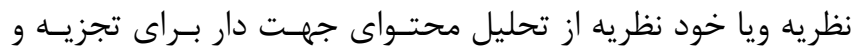

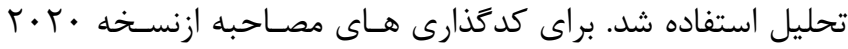

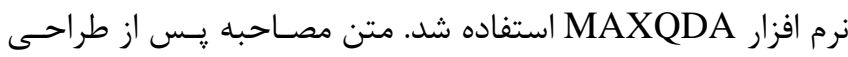

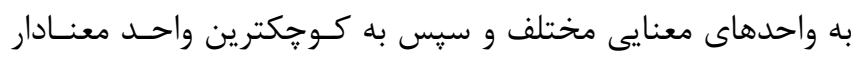

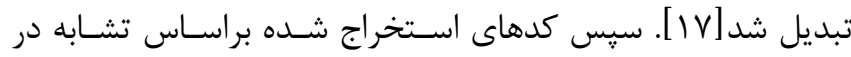
طبقات و زير طبقـات اصـلى قـرارداده شـدند. كليـهـ كى كـدها، زيــر

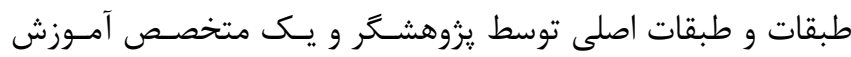

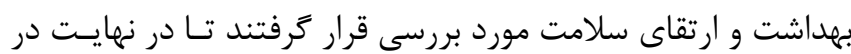
مورد طبقات به توافق نظر رسيدند.

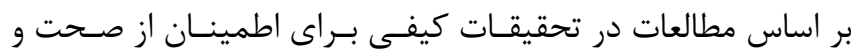

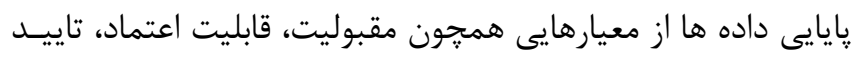
يذيرى و انتقال يذيرى به عنوان معيارهاى دقت علمى استفاده مسى إنى

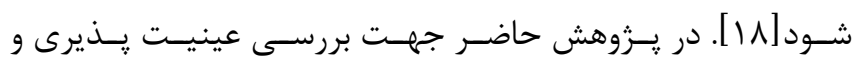

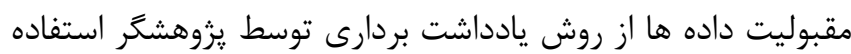

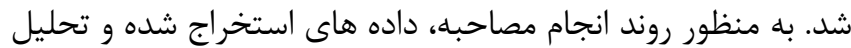

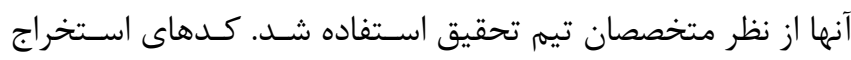

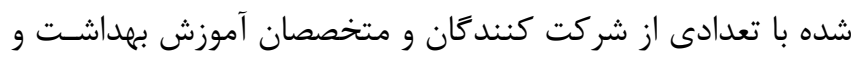

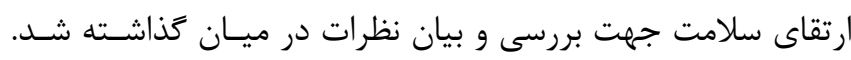

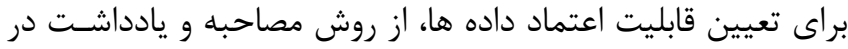

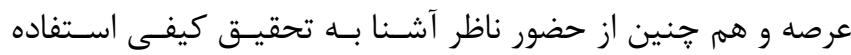

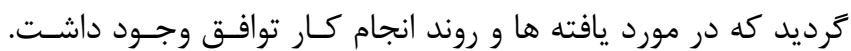
براى تعيين تاييد يذيرى داده ها كليه مراحـل انجـام كـار، نحـوه ى

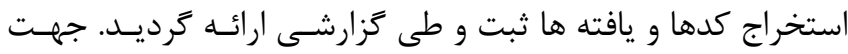

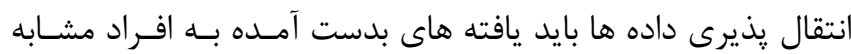

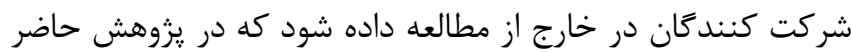
يافته ها در اختيار ب نفر از معلمان قرار كرفت و به به تاييد آنها رسـيد. در اين مطالعه ضمن بعداز كسب تاييديه علمى اخلاقى بـراى انجـام
از شركت كنندكان در يزوهش كرد. نمونسه هـا كـهـ معلمـان مقطـع

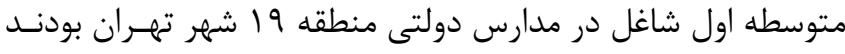

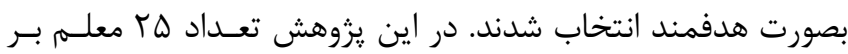
اساس معيارهاى ورود به يزوهش شامل داشتن شغل معلمى، داشتن

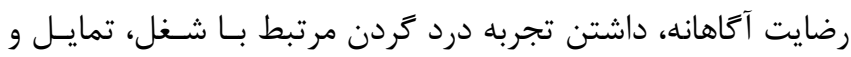

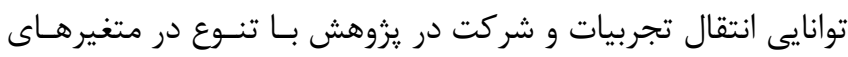

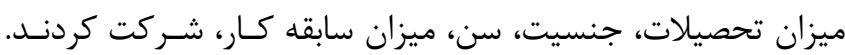

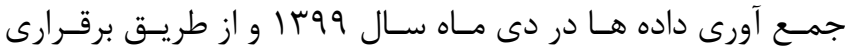

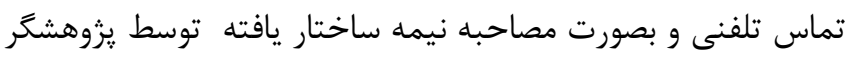

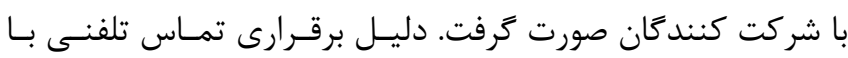

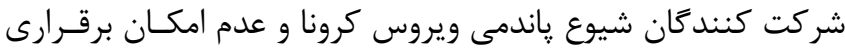

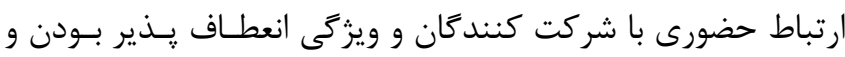

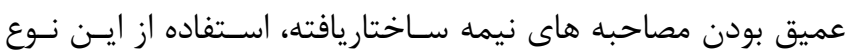

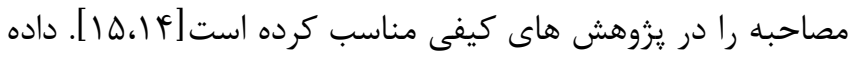

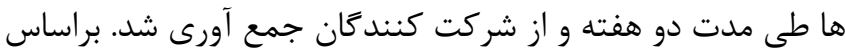

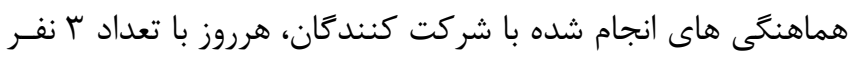

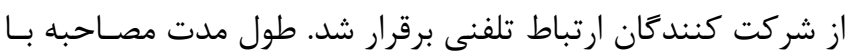

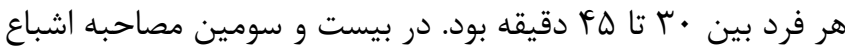
داده ها حاصل شد و طبقات اوليه شـكل كرفـت امـابراى اطمينـان

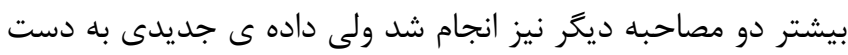

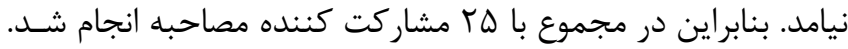

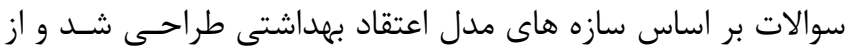

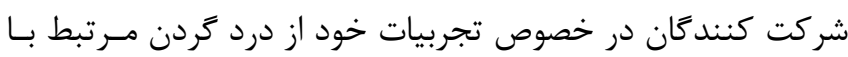

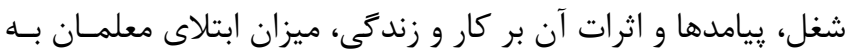

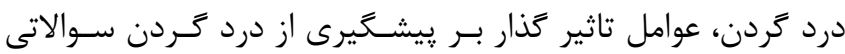

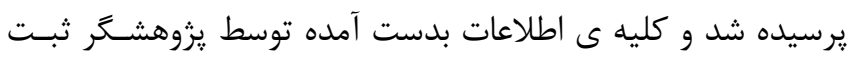

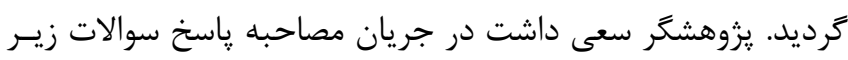

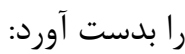

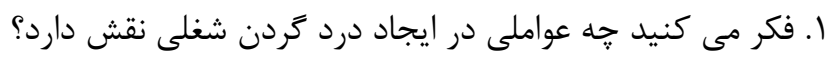

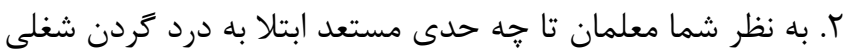

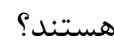

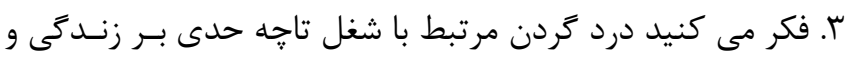

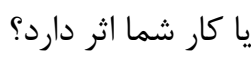

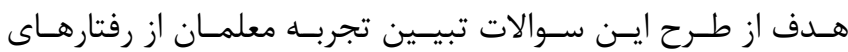

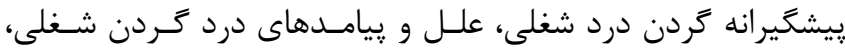

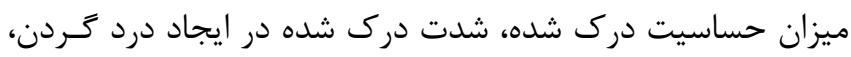


تو اين لب تاب و گوشى گردنمون درد مى كيره ، كاش زودتر كرونـا

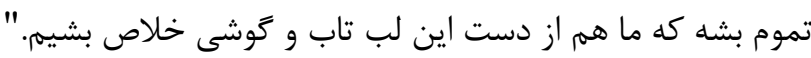
r.حساسيت دركى شــده: عقايـــ فـرد در مـورد احتمـال ابـتلا بـهـ

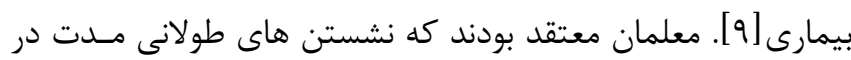

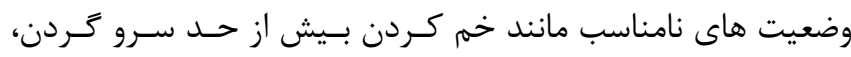
داشتن استرس و اضطراب و نداشتن فعاليت ورزشى مناسب، افزايش

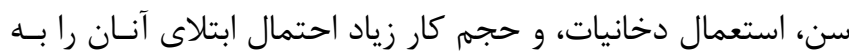

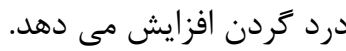

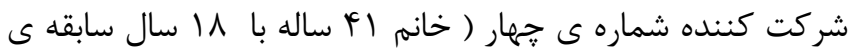

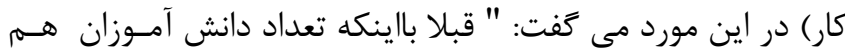

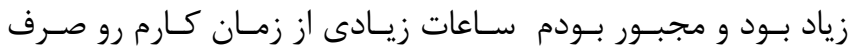

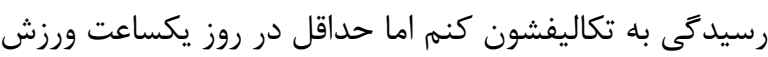

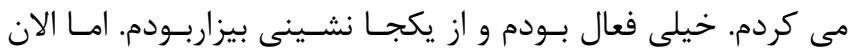

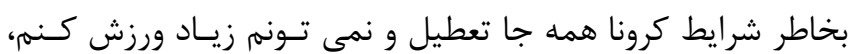

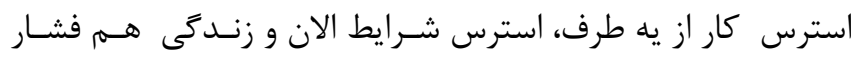

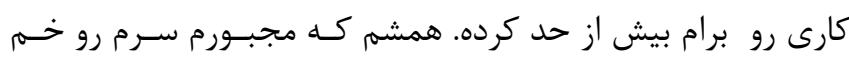

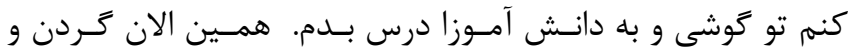

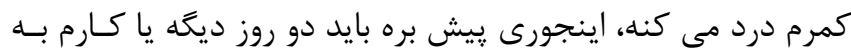

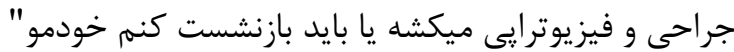

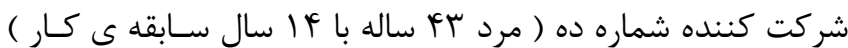

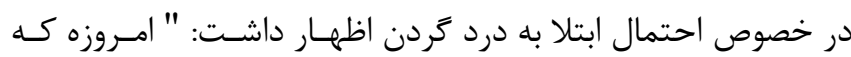

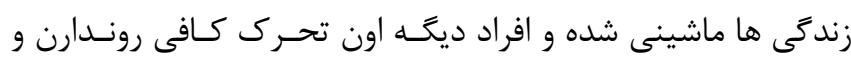

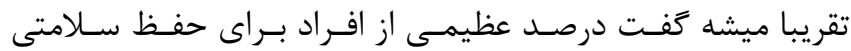
ورزش نمى كنن و خيلى ها هم به دلايل مختلـف و بـراى رهـايى از از

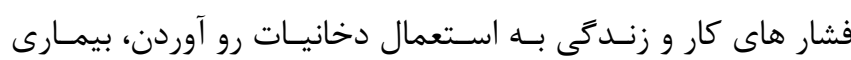
هاى مزمن خيلى بيشتر از قبل شده و خود همين عوامل روى تمار تمام اعضاى بدن و ازجمله ساختار اسكلتى عضلانى افراد تاثير منفى داره

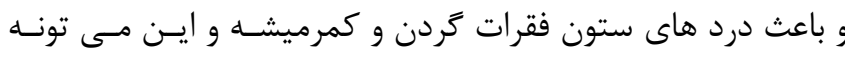

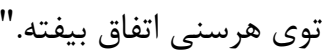

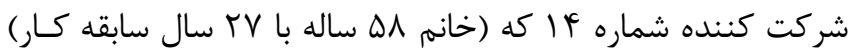

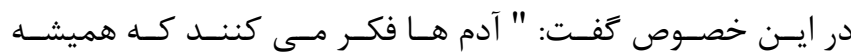

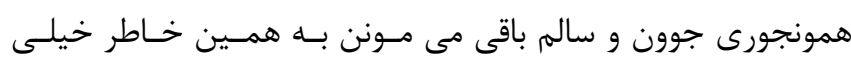

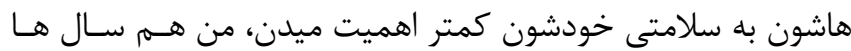

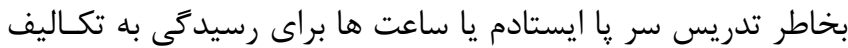

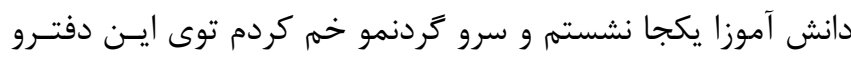

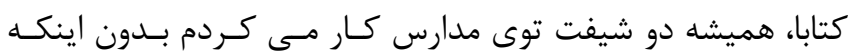

يزوهش در دى ماه 99 ا | از دانشكاه تربيت مدرس، كسـب رضـايت

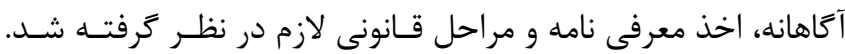

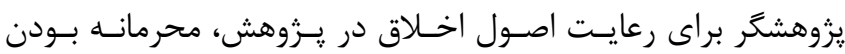

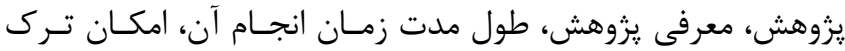

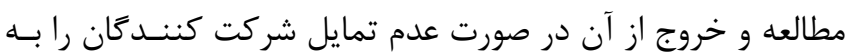

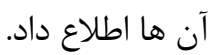

يافتهها دريزوهش حاضر تعداد ها نفر از معلمان شاغل در مدارس ( 1 إنفر

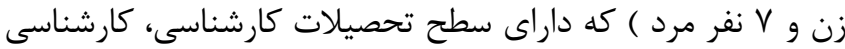

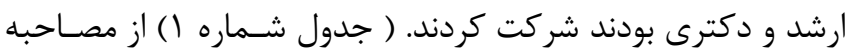

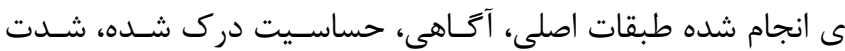

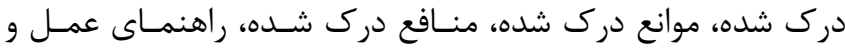

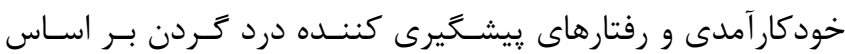

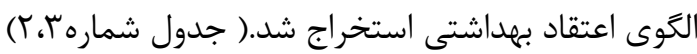

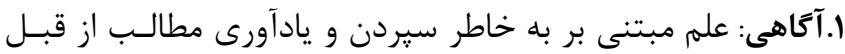

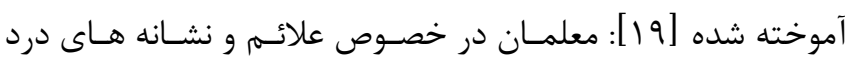

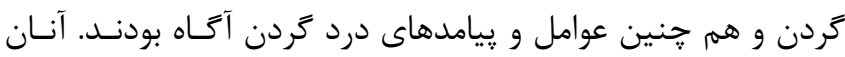

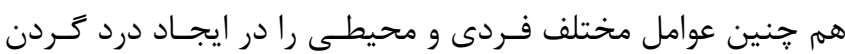

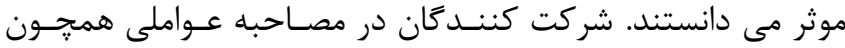

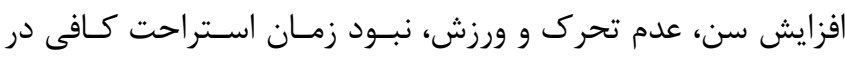

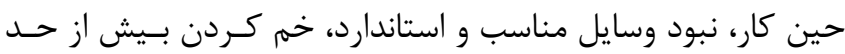
كردن براى ساعات طولانى را بيان كردند.

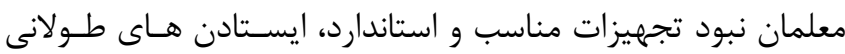

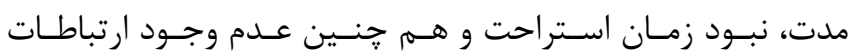
اجتماعى سالم رالز دلايل ايجاد درد كردن مى دانستند

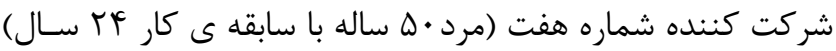

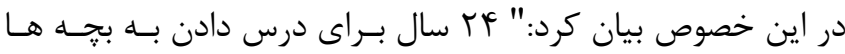

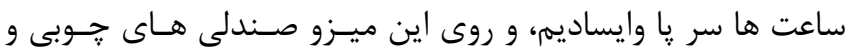

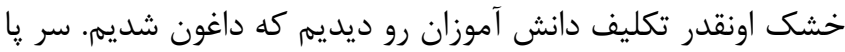

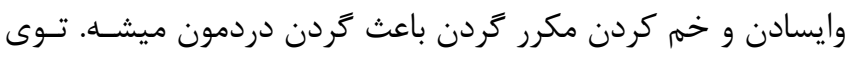

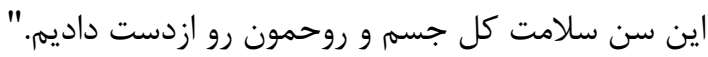

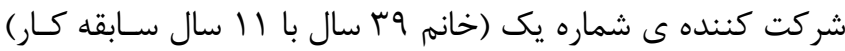

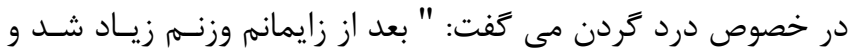

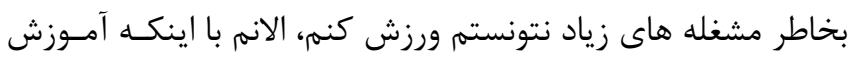

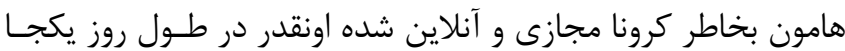
ميشينيم و هيج تحرك و ورزشى نداريم و سرمون رو خمى مى كنسيم 
بالاى كار، كمبود تجهيزات استاندارد و عدم حمايت مديران و مســئولين

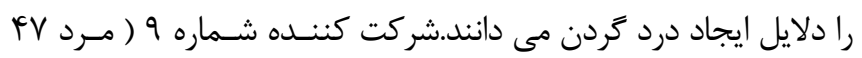

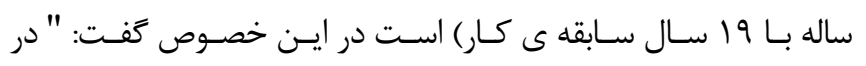

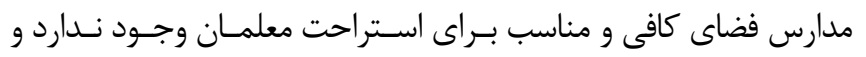

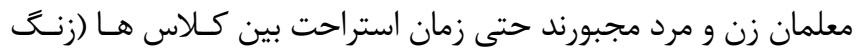

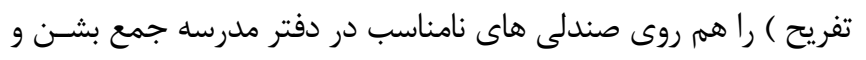

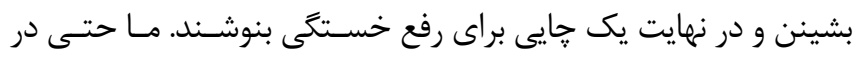

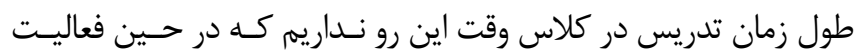
جندتا حركت كششى ساده انجام بديم."

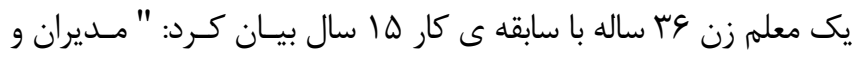

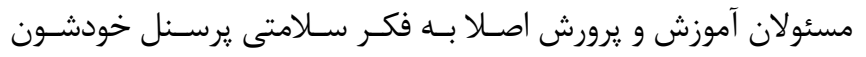

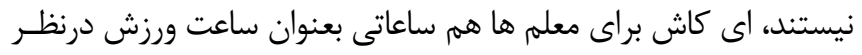

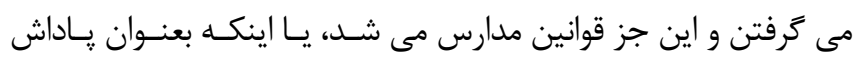

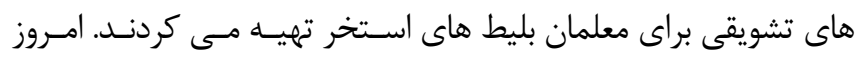

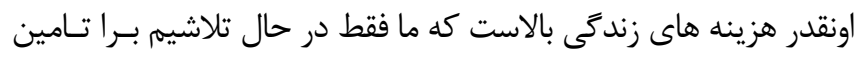

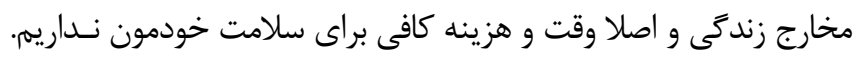

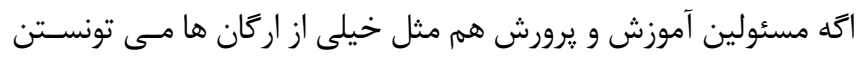

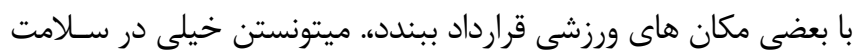
يرسنلشون موثر باشن."

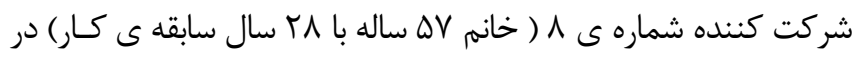

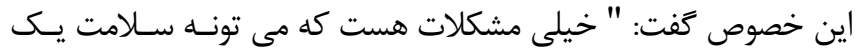

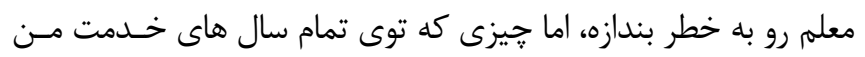

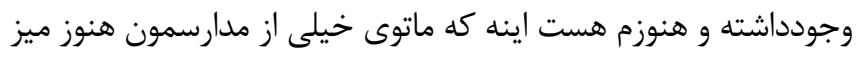

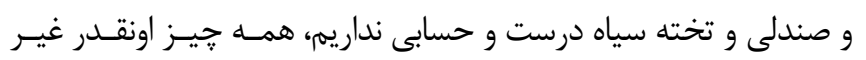

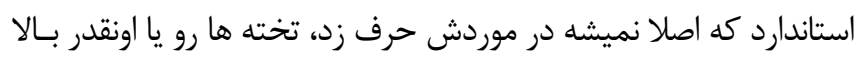

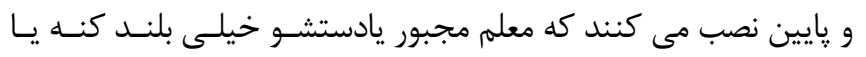

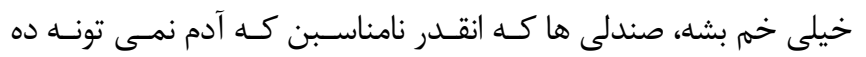
دقيقه روشون بشينه و كل ستون فقراتت درد مي گيرها.

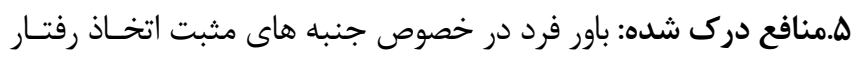

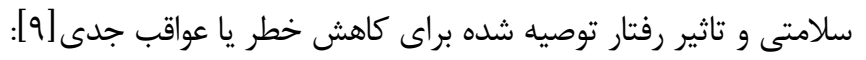
انجام رفتارهاى ارتقا دهنده ى سلامت كردن و يِيشَيرى و كاهش ايـن

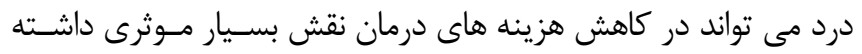

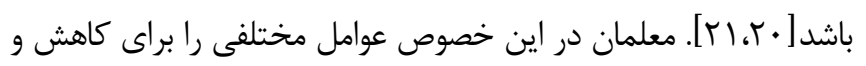
ييشخيرى از درد كردن بيان كردند.

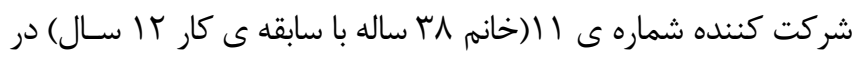

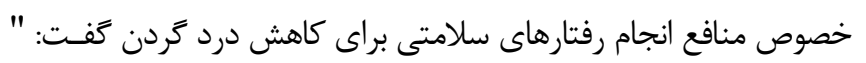

ورزش كنم يا استراحت كافى داشته باشم. هميشه فكـ مسى كـردم كسه درد كردن و كمر فقط براى افراد خيلى مسنى كه كارهاى خيلى سـخت

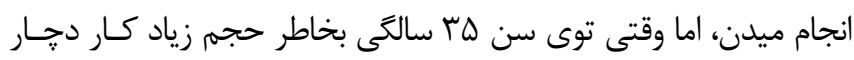

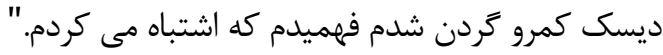

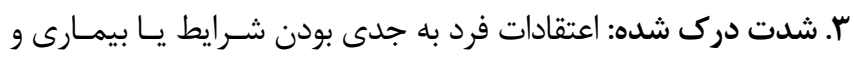

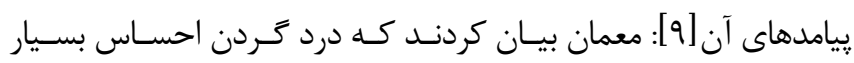

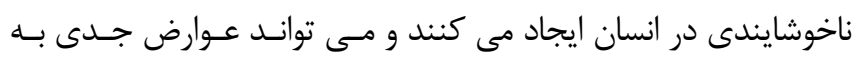

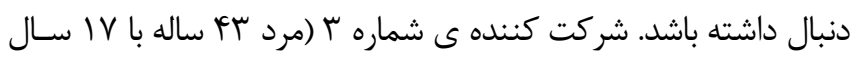

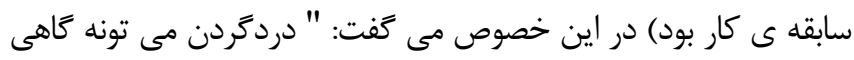

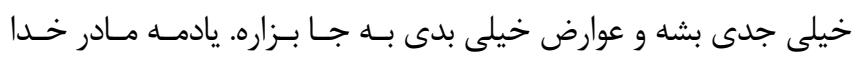

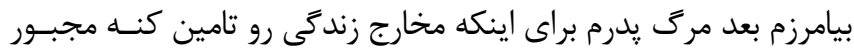

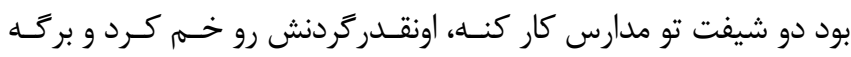

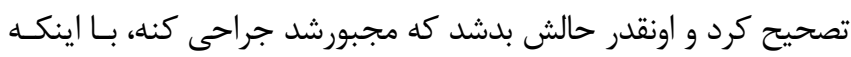

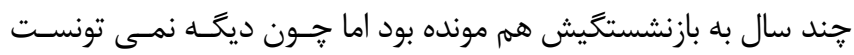

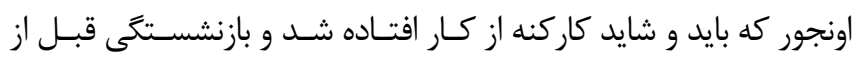

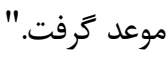

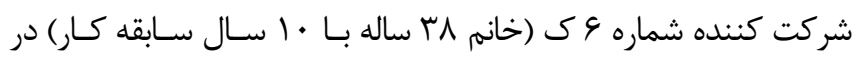
اين خصوص بيان كرد: " با اينكه خيلى هم سنى ندارم اما ايـن ده سـال

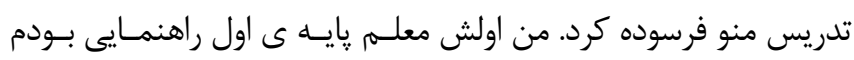

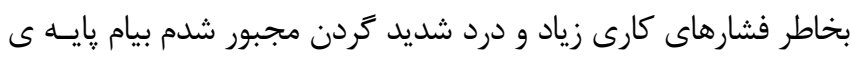

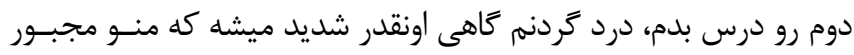

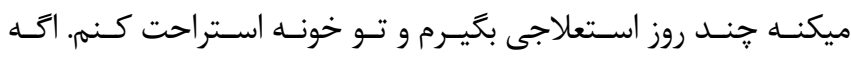

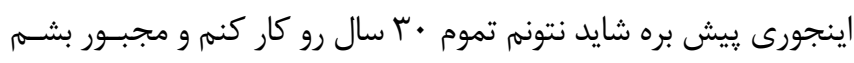
خيلى زود بازنشست بشم. "

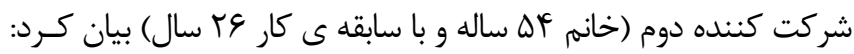

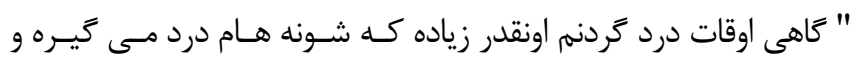

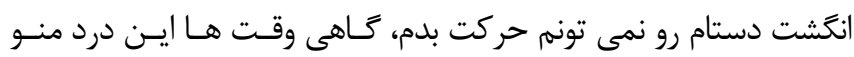

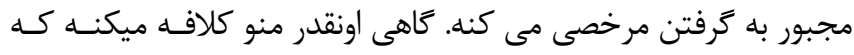

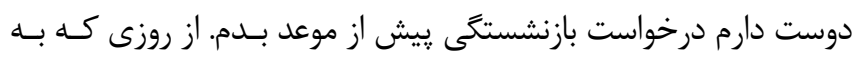

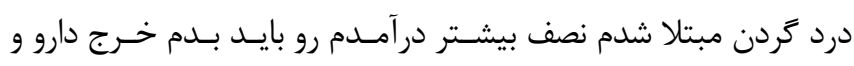

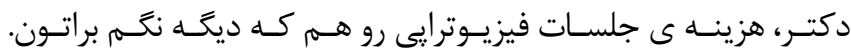

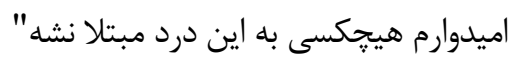

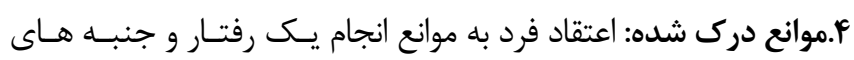

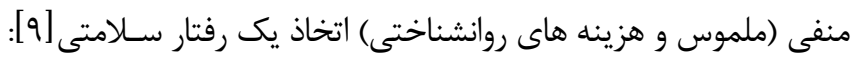

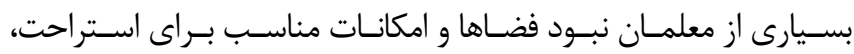

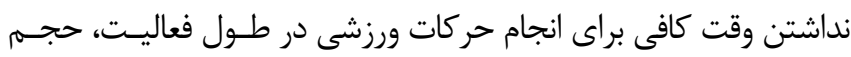


شركت كننده شماره r اكه( خانم •r ساله با ا سال سابقه كار) در ايـن

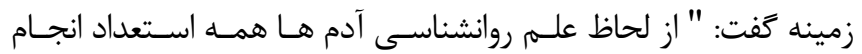

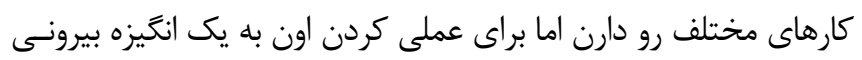
يا درونى نياز دارن، توى محيط هاى كارى همكـاران مسى تـونن موتـور

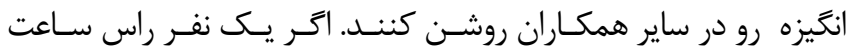

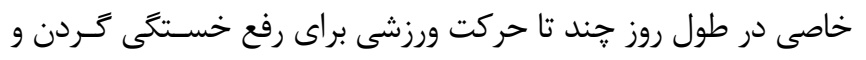

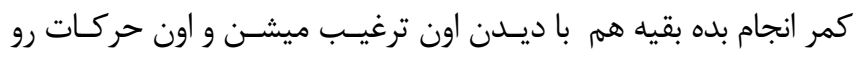

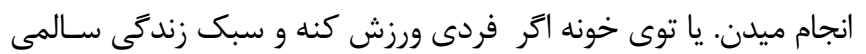

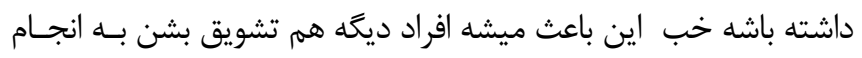
شركت كنندكان بر نقش موثر مديران و مسئولان مـدارس و آمـوزش و

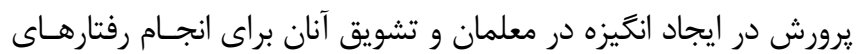

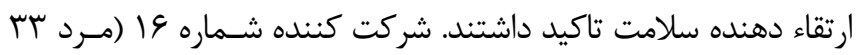

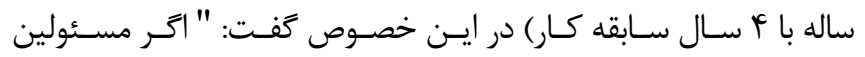

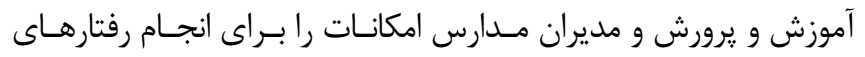

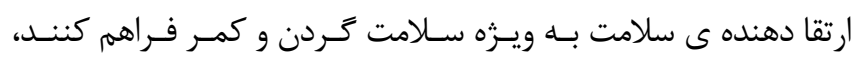

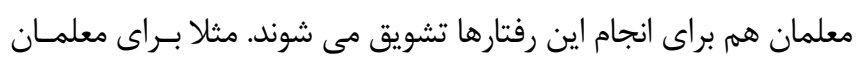

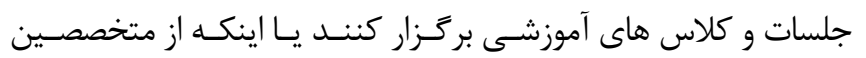

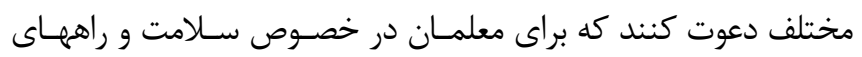

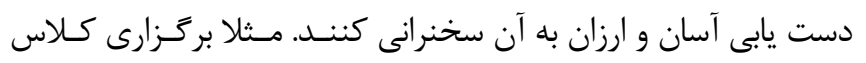

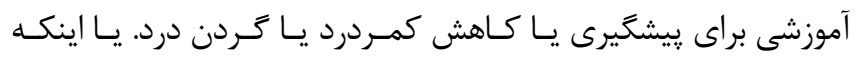

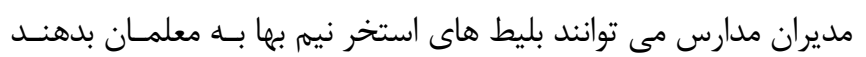

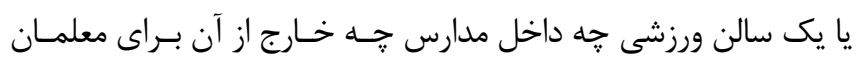

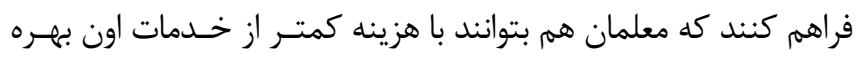

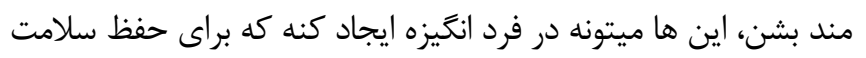
خودش تلاش كنه." - ( هم جنين شركت كننده شماره VI كه( خانم צr ساله با 9 سال سـابقه كار) بود در اين زمينه اظهـار داشـت : " رسـانه هــاى اجتمـاعى هـم در

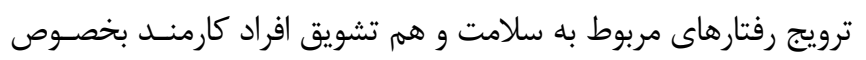

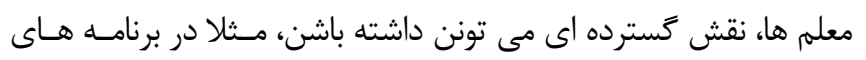

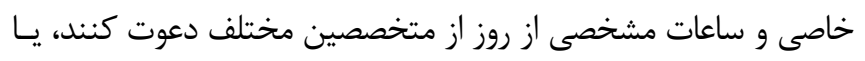

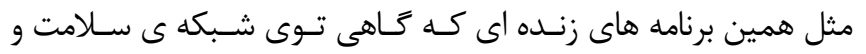

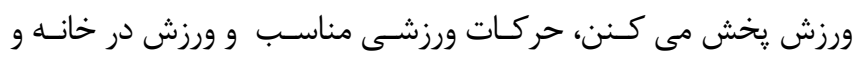
محل كار رو به افراد آموزش بدن."

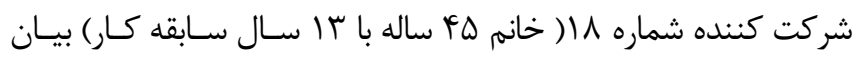
كرد: " درسته كه ما هميشه وقت كافى بــراى ورزش كـردن نـداريم امـا
خيلى از افراد اطلاعات و آكَاهى هاى خوبى در مورد سـلامتى و راههـاى

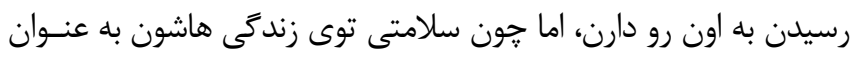

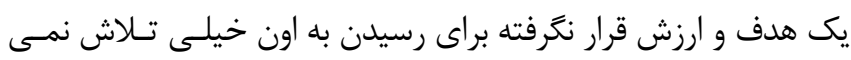

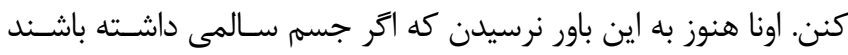

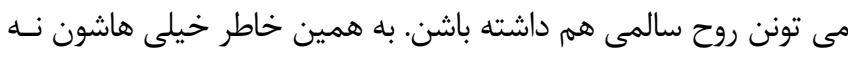

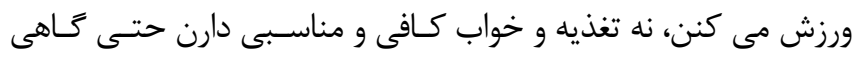

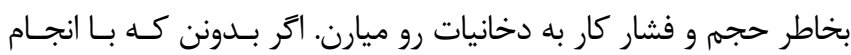

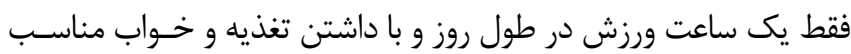

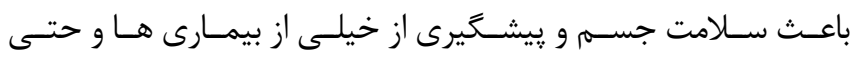

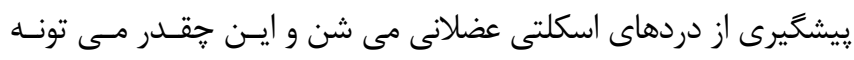

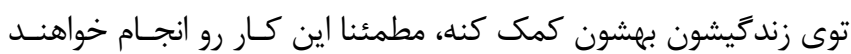

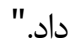
شركت كننده شماره سا (خانم F ب ساله با 1 سال سـابقه كار) در ايـن

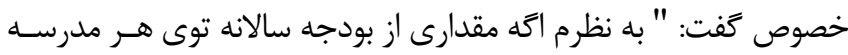

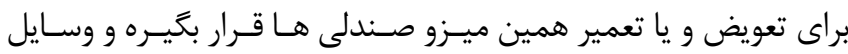

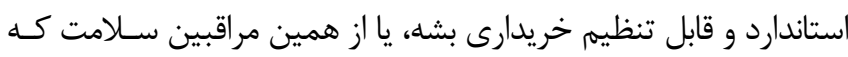

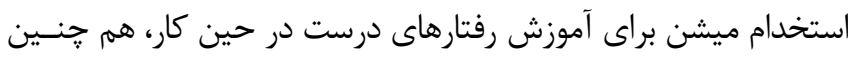

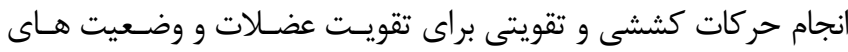

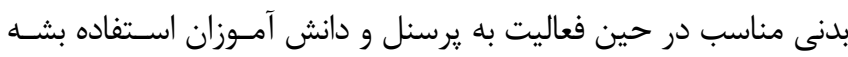
اين همه مشكل كردن درد و كمردرد كمتر ميشه."

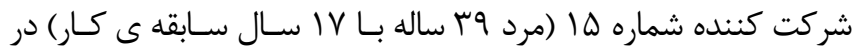
خصوص انجام حركات ورزشى مناسب و كنترل اسـترس در يِيشـيرى

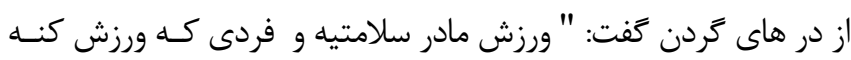

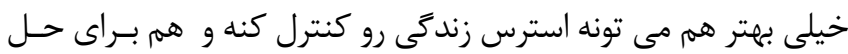

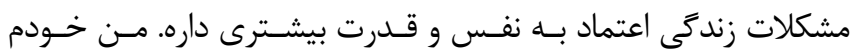

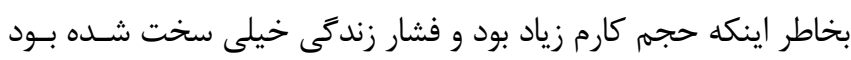

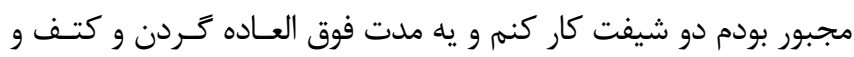

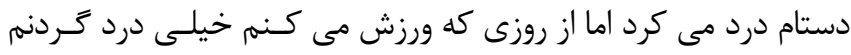

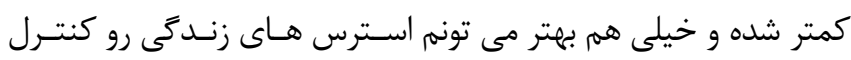
كنه." كمنر ش צ. راهنماى عمل: عوامل داخلى يا خارجى كه مى توانند باعـث تحريـى

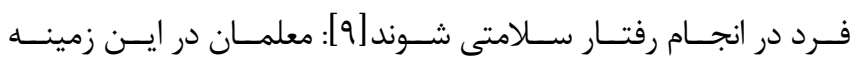

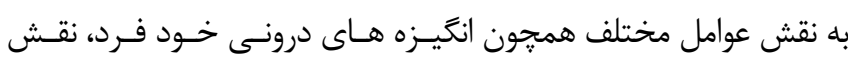

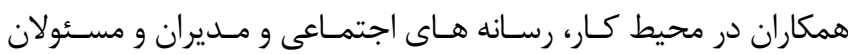

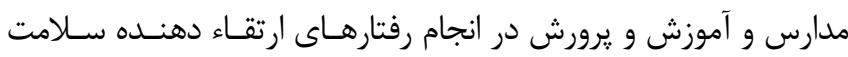
كردن تاكيد داشتند. 
در اين موردمى خونم، هميشه برنامه هاى مربوط بـهـ سـلامتى رو از

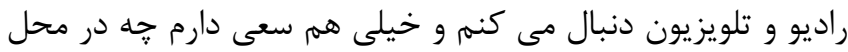

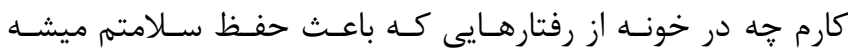

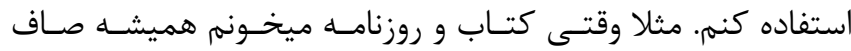
ميشينم و كردن و كمرم رو زياد خم نمى كنم، بين كارام حتمـا ها ها

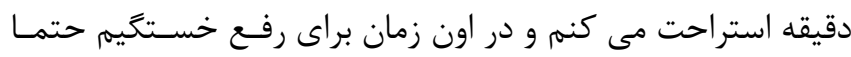

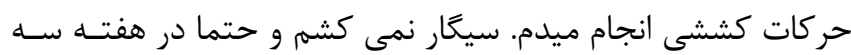

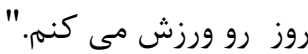

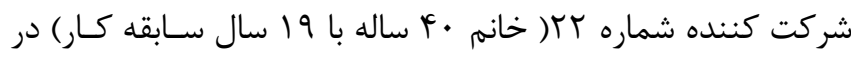

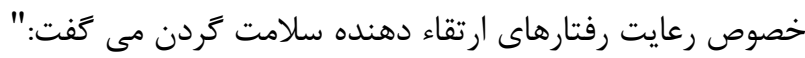

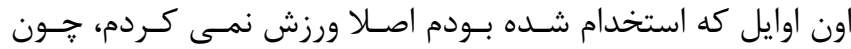

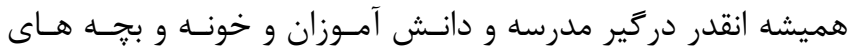

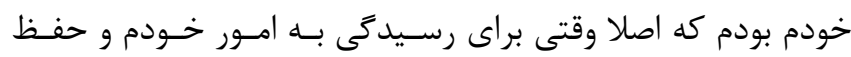

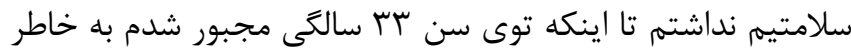
ابتلا به ديسك كردن كلى وقت و هزينه صرف درمان كنهم، بعـد اون

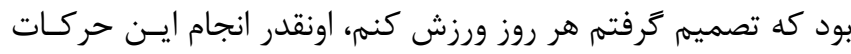

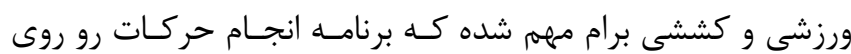

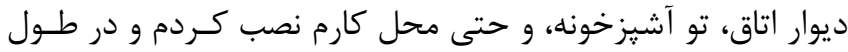

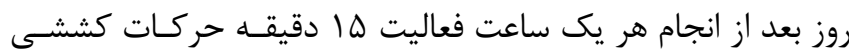

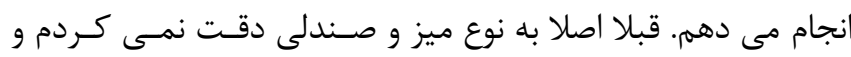
ساعت ها از ميز و صندلى هاى غير استاندارد استفاده مى كردم امـاـ

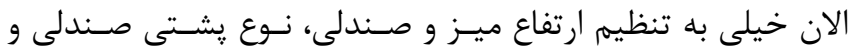

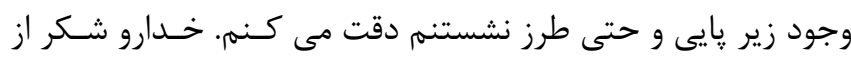
وقتى اين كار ارو انجام مى دهم خيلى درد كردنم كمترشده نس ."

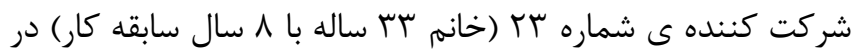

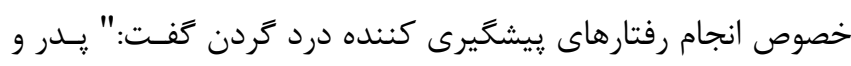
مادرم همم معلم بودند و يدرم بخاطر ديسك كمر مجبور شد قبـ إنسل از

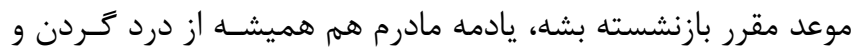

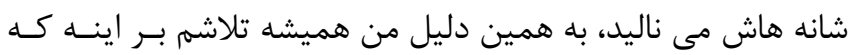

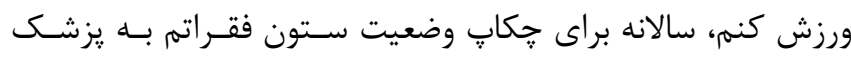
مراجعه كنه، و هميشه موقع نشسـتن، ايسـتادن و حتسى راه رفـتن وضعيت درست رو براى ستون فقرات كردن و كمرم بكار بخيرم".
مسئولين در هر محيط كارى مسى تـونن در ترغيـب يرسـنل بـهـ ورزش

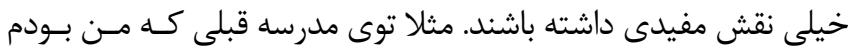
روى ديوارهاى تمامى كلاس ها يوسترهاى آموزشى حركـات كششى و وديدي

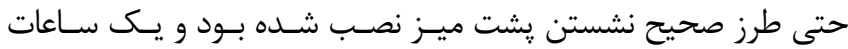

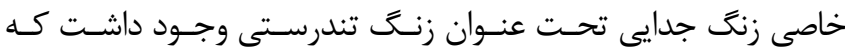

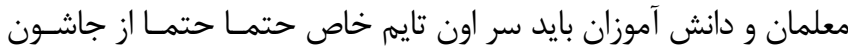

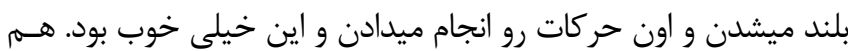

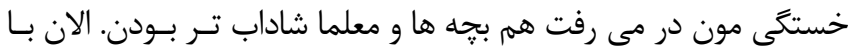

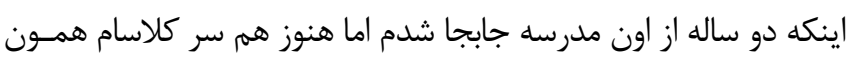
ساعت ها بجهه هارو دعوت به انجام اون حركات مى كنم. V. خودكار آمدى: باور فرد به اينكه مى تواند رفتارهاى سـلامتى توصسيه شده را انجام دهد ( اعتماد به نفس )، اين مفهوم سطح عملكرد و تـلاش

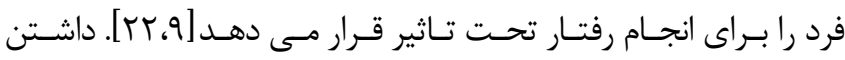

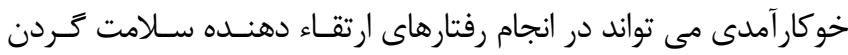

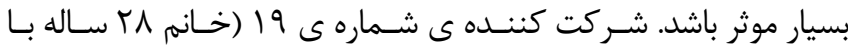

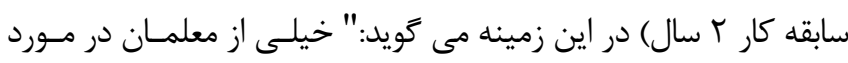

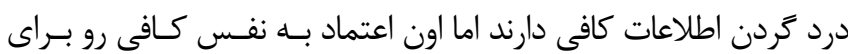

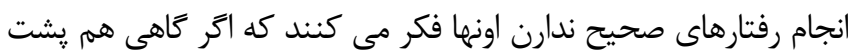

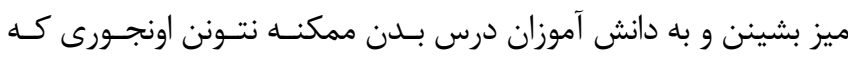

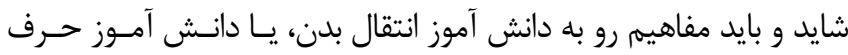
شنوى كافى رو از اونها نداشته باشه."

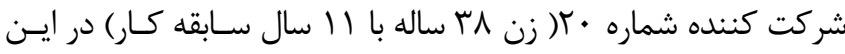

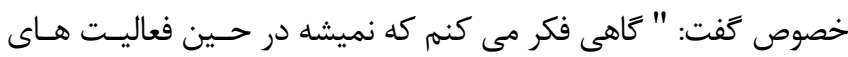
روزمره در محيط كار و خونه خيلى از وضعيت هاى درست استئ استفاده كرد

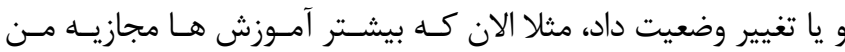

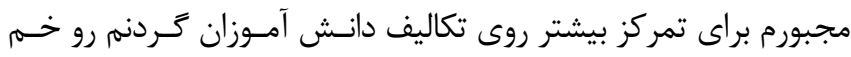

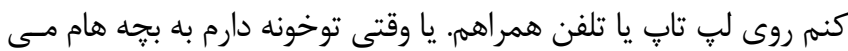

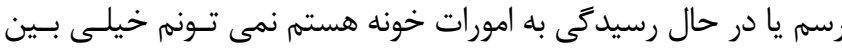

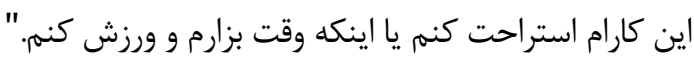

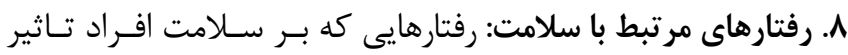

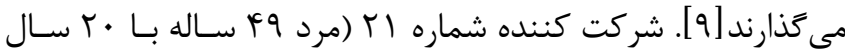

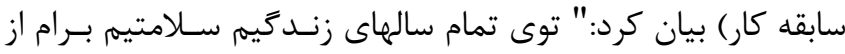

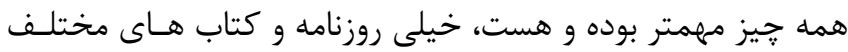


سال بيستم، شماره ششم، آذر ـدى ..1f

\begin{tabular}{|c|c|c|c|c|c|}
\hline \multirow[b]{2}{*}{ سابقه كار } & \multirow[b]{2}{*}{ وضعيت تاهل } & \multirow[b]{2}{*}{ سطح تحصيلات } & \multirow[b]{2}{*}{ جنسيت } & \multicolumn{2}{|c|}{ جدول ا: ويزَكى شركت كنندَّان در مصاحبه } \\
\hline & & & & سن & شركت كنندگًان \\
\hline 11 & متاهل & كارشناسى & زن & rq & 1 \\
\hline re & متاهل & 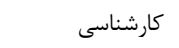 & 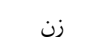 & $\Delta F$ & r \\
\hline iv & متاهل & 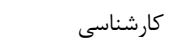 & مرد & qr & r \\
\hline 11 & متاهل & 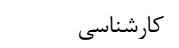 & 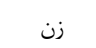 & il & f \\
\hline 10 & متاهل & 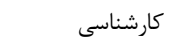 & زن & re & $\Delta$ \\
\hline 1. & متاهل & 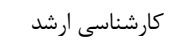 & 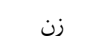 & rی & \& \\
\hline rF & متاهل & 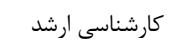 & مرد & $\Delta \cdot$ & $\checkmark$ \\
\hline rs & متاهل & 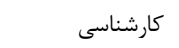 & 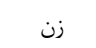 & $\Delta V$ & $\wedge$ \\
\hline 19 & متاهل & 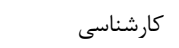 & مرد & iv & 9 \\
\hline if & متاهل & دكترى & مرد & qr & 1. \\
\hline IT & متاهل & دكترى & زن & rı & 11 \\
\hline 1 & متاهل & دكترى & زن & $r$. & ir \\
\hline$\wedge$ & متاهل & كارشناسى ارشد & زن & re & Ir \\
\hline TV & متاهل & كارشناسى & زن & $\Delta \Lambda$ & if \\
\hline IV & متاهل & كارشناسى & مرد & чq & 10 \\
\hline$r$ & متاهل & كارشناسى ارشد & مرد & rr & 19 \\
\hline 9 & متاهل & كارشناسى & زن & re & IV \\
\hline ir & متاهل & كارشناسى ارشد & زن & $i \Delta$ & 11 \\
\hline r & متاهل & كارشناسى & زن & $r \wedge$ & 19 \\
\hline 11 & متاهل & كارشناسى & زن & ru & r. \\
\hline$r$. & متاهل & كارشناسى ارشد & مرد & $4 q$ & rI \\
\hline 19 & متاهل & كارشناسى & زن & r. & rr \\
\hline$\wedge$ & متاهل & كارشناسى & زن & r & rr \\
\hline ra & متاهل & كارشناسى ارشد & زن & $\Delta V$ & TF \\
\hline if & متاهل & كارشناسى & زن & il & ro \\
\hline
\end{tabular}

\begin{tabular}{|c|c|}
\hline كدها & واحد معنايى \\
\hline 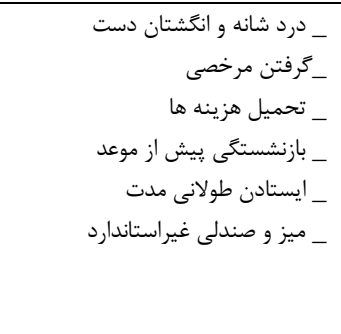 & 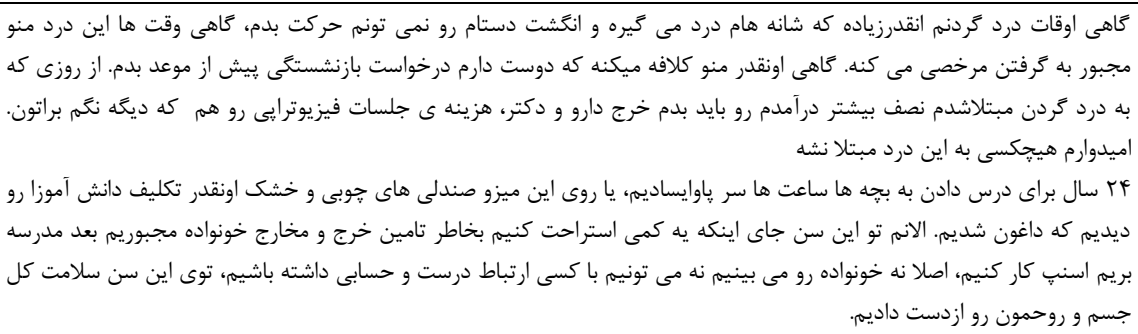 \\
\hline 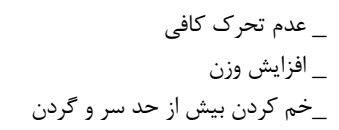 & 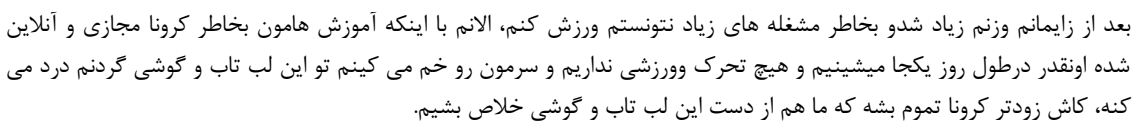 \\
\hline 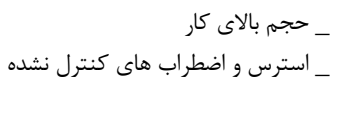 & 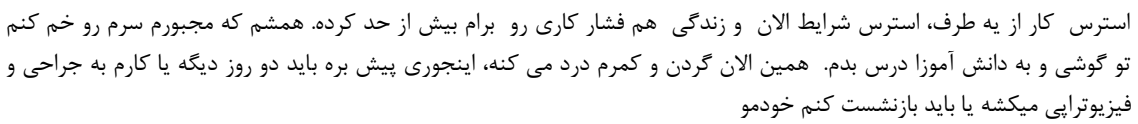 \\
\hline 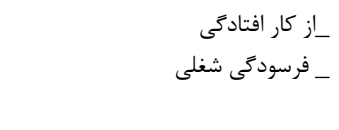 & 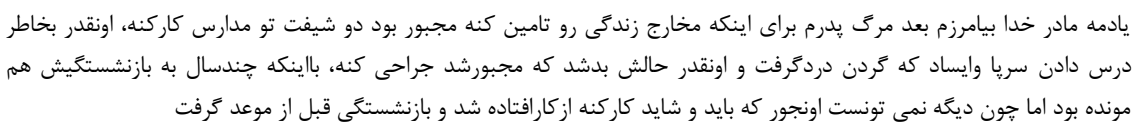 \\
\hline 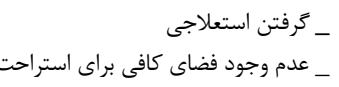 & 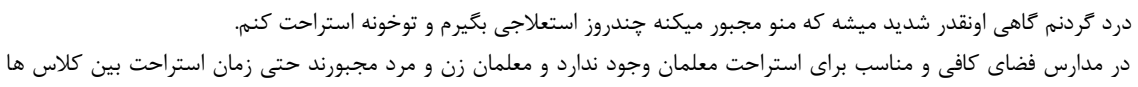 \\
\hline
\end{tabular}


نشريه يُوهشكده علوم بهداشتى جهاددانشكاهى

ـ عدم وجود زمان استراحت كافى حين كار.

_ عدم وجود قوانين ورزش عدم وجود امكانات رواهي بـ

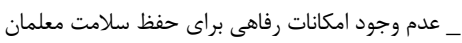

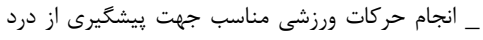

داشتن استراحت، تغذيه و خواب كافى

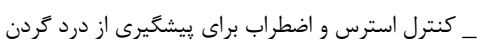

ـ ـقش همكاران در ترغيب افراد براى رعايت رفتارهاى ارتقا دهنده سلامت تردن

_ نقش رسانه هاى اجتماعى در تشويق افراد

ـ ـقش مديران و مسئولان در ترغيب معلمان

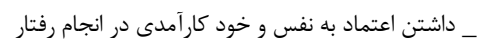

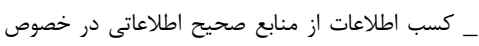

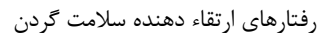

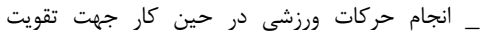

$$
\text { _ _ عرى دخلات كردن }
$$

_ـ استفاده از ميز و صندلى استاندارد

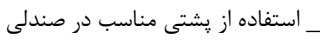

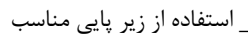

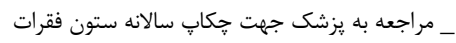

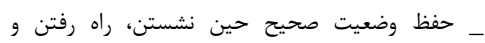

(زنح تفريح ) را هم روى صندلى هاى نامناسب در دفتر مدرسه جمع بشن و بشينن و در نهايت يك جايى براى رفع خستگى بنوشند.ما

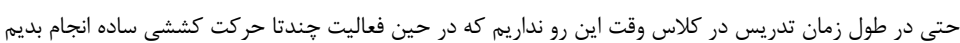

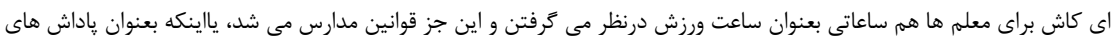

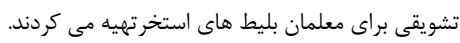

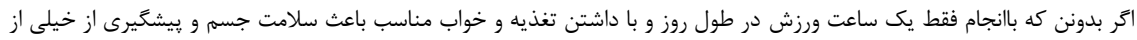

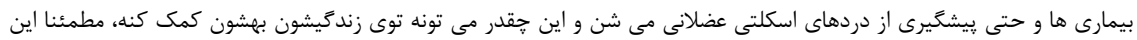
كاررو انجام خواهندداد ورزش مادر سلامتى و فردى كه ورزش كنه خيلى بهتر هم مى تونه استرس زندگى رو كنترل كنه و وهم براى حلى حل مشكلات زندىى

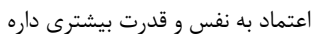

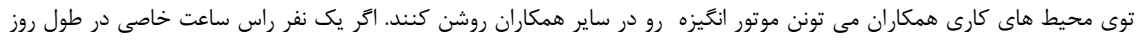

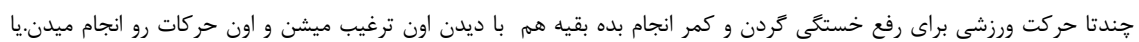

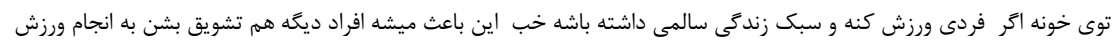

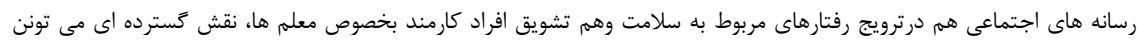
داشته باشن

مسئولين در هر محيط كارى مى تونن در ترغيب يرسنل به ورزش خيلى نقش مفيدى داشته باشند

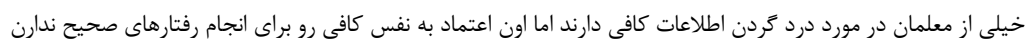

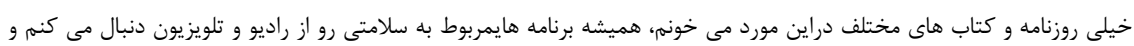

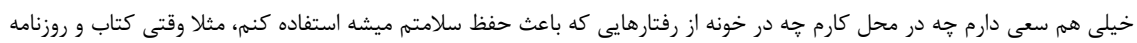

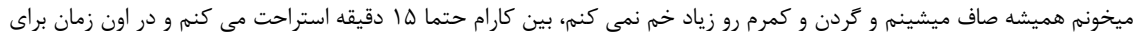

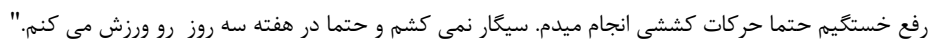

قبلا اصلا به نوع ميز و صندلى دقت نمى كردم و ساعت ها از ميزو صندلى هاى غير استاندارد استفاده مى كردم اما الان خيلى به تنظيم

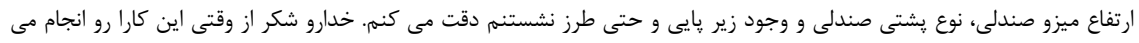
دهم خيلى درد كردنم كمترشده

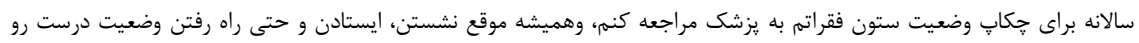
براى ستون فقرات گردن و كمرم بكاربخيرم

جدول سا: روند شكل تيرى طبقات

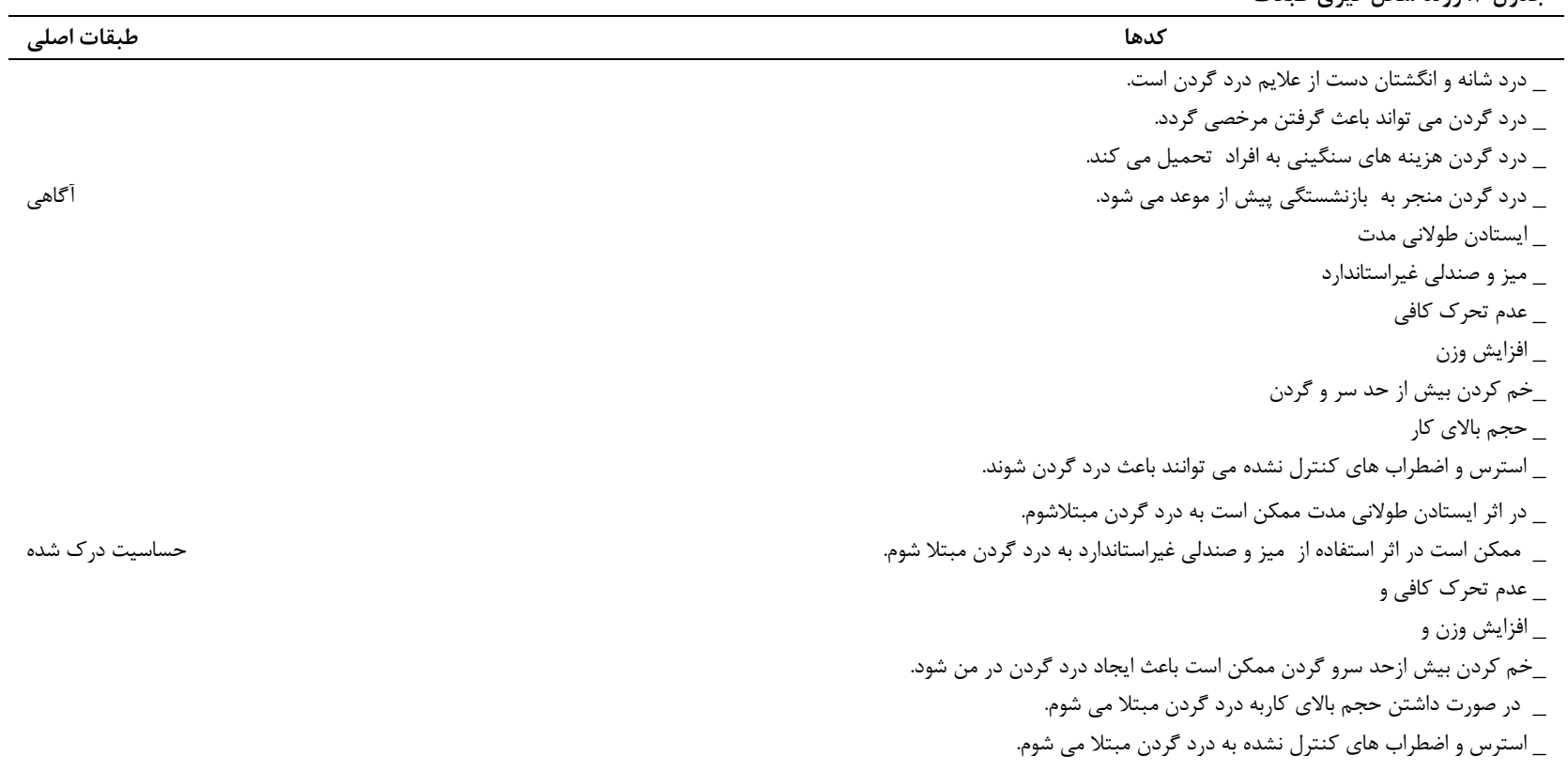


سال بيستم، شماره ششم، آذر ـدى ..1f

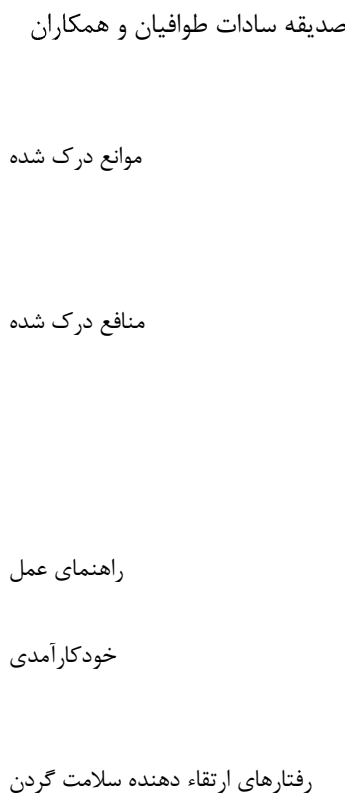

تببين علل درد كردن و رفتارهاى ييشَيرانه ...

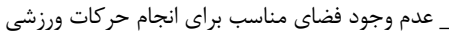

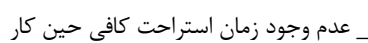

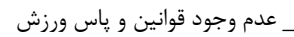

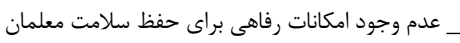

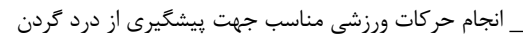

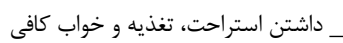

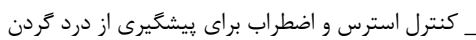

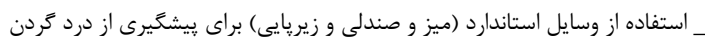

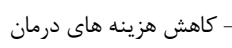
ــ ـ ـقش همكاران در ترغيب افراد براى رعايت رفتارهاى ارتقاء دهنده سلامت كَردن

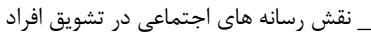

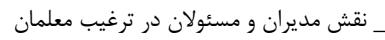

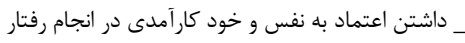

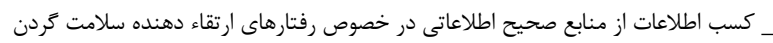

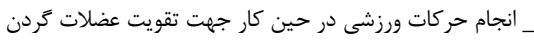

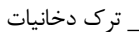

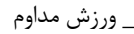

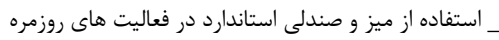

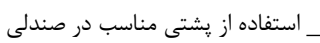

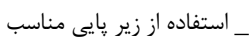

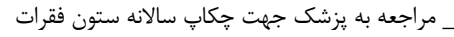

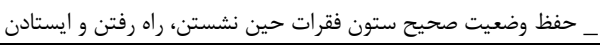

جدول ا: اطلاعات جمعيت شناختى شركت كنندكان در مصاحبه

\begin{tabular}{|c|c|}
\hline درصد & فراوانى \\
\hline 4 & $q$ \\
\hline $9 / 9$ & 1. \\
\hline r// & $4 \lambda$ \\
\hline $9 / 9$ & 10 \\
\hline$r / / \Lambda$ & זr \\
\hline $15 / 9$ & $r$ \\
\hline f & 4 \\
\hline 9 & 9 \\
\hline
\end{tabular}

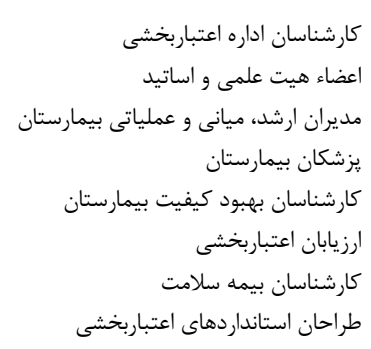

متغير

دקصد

فراوانى

درصد

$\begin{array}{ll}r V / \Lambda & \Delta V \\ G T / Y & q F\end{array}$

جنسيت

$\Delta V$

q4 كمتر از • 1 سال

ت تحصيلات

$\begin{array}{ll}r F / \Delta & r r \\ r Y & \Delta q \\ r q / \Lambda & r Q \\ N / 9 & 1 r\end{array}$

so
ir
r
q
r
r

\section{سابقه كار} •rr.

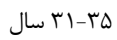

$19 / 4$

re

$r V / \Lambda$

سابقه اعتباريخد

$$
\begin{aligned}
& \text { كمتر از ه سال } \\
& \text {. 1- ه سال } \\
& \text { ها-11 ال سال } \\
& \text {. }
\end{aligned}
$$

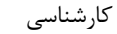

كارشناسى ارشد

دكترا 
نشريه يروهشكده علوم بهداشتى جهاددانشكاهى

جدول ז: جالشهاى اصلى و فرعى و راهكارهاى روش ارزشيابى اعتباربخشى بيمار ستانى ايران

\begin{tabular}{|c|c|c|}
\hline راهكارها & 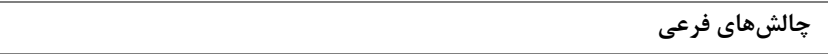 & جالشهاى اصلى \\
\hline 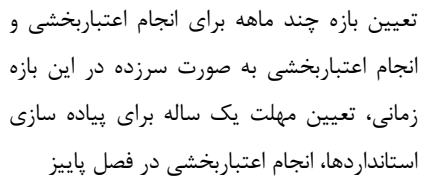 & 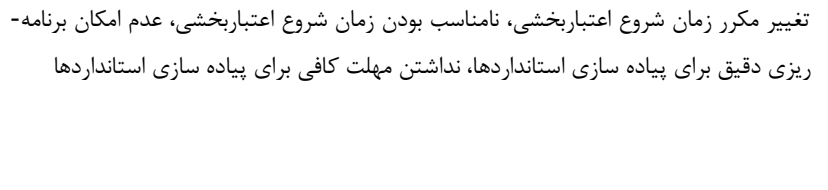 & زمان اعتباربخشى \\
\hline 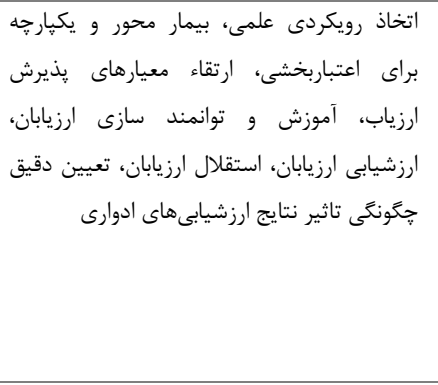 & 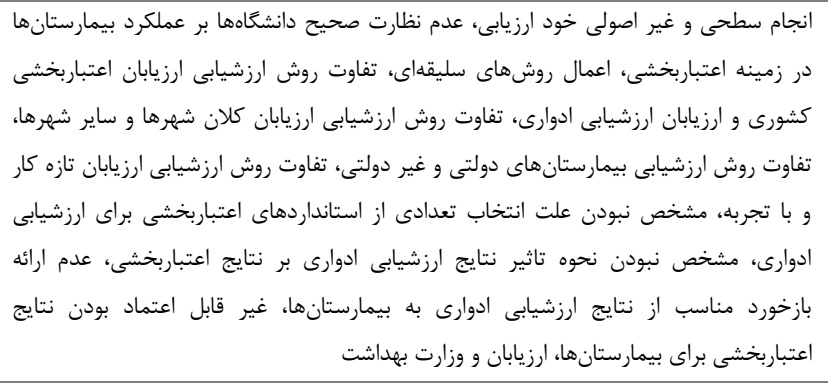 & 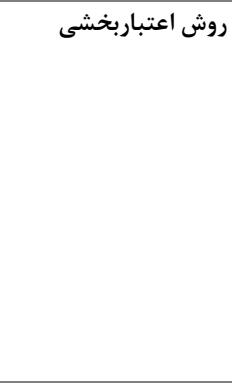 \\
\hline توسعه دانش و مهارت ارزيابان & عدم مديريت صحيح زمان، انجام ارزشيابى سطحى، خستكى ارزيابان، افزايش بى دقتى & طول مدت اعتباربخشى \\
\hline 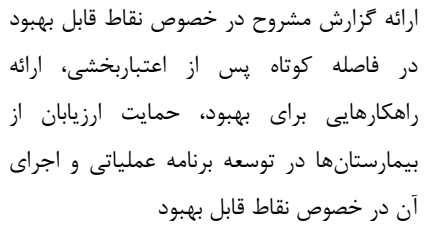 & 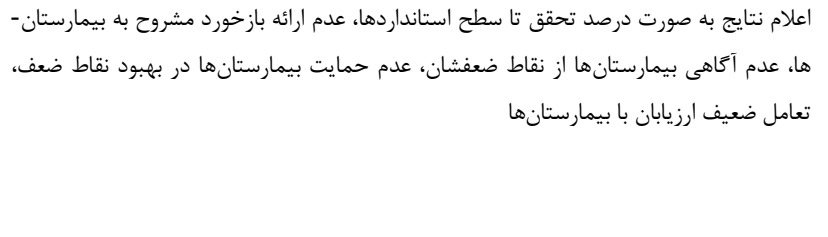 & 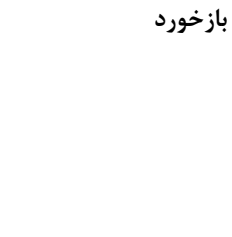 \\
\hline 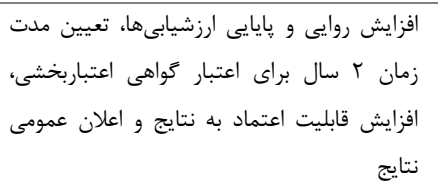 & 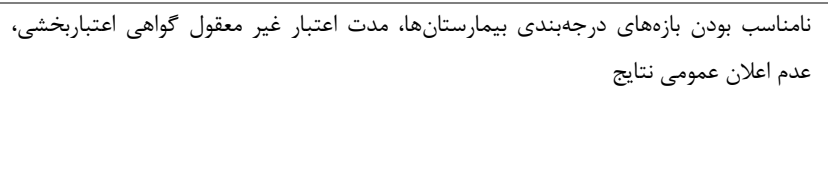 & كواهينامه اعتباربخشى \\
\hline
\end{tabular}

غيبت از كـار، از كارافتـادگى، بازنشسـتخى يـيش از موعـد، و عـدم رتباط موثر در انجام فعاليت هاى آنان نقش داشته باشد. از آنجا كه به

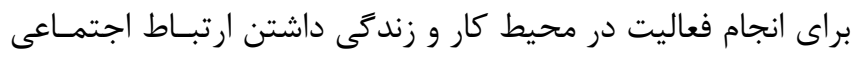

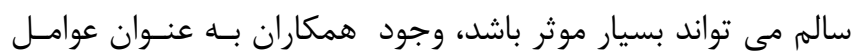
تقويت كننده يا راهنما براى عمل مى توانـد در انجـام رفتــار بسـيار

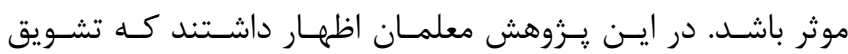

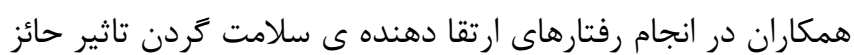

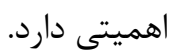
با توجه به اينكه در مدارس معلمان ركن اصـلى آمـوزش و يــرورش

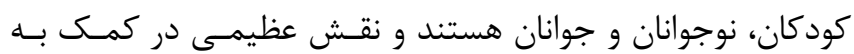

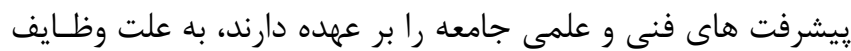

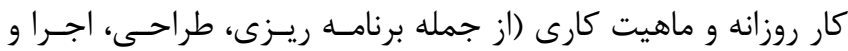

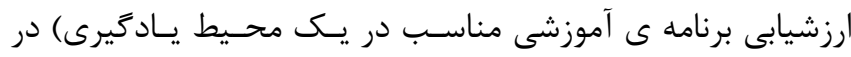

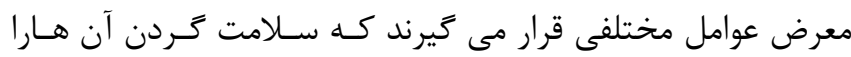

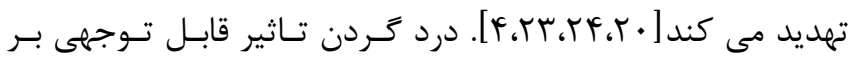

\section{بحث و نتيجه گيرى}

يزوهش كيفى حاضر براى شناسايى عوامل موثر در ايجاد درد گردن

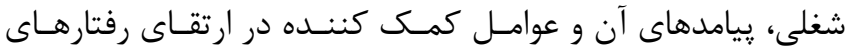

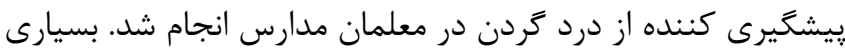

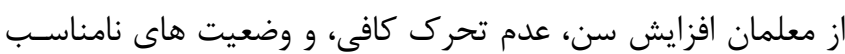
بدنى حين فعاليت را عامل درد گردن بيان كردند. يافته هاى حاصل

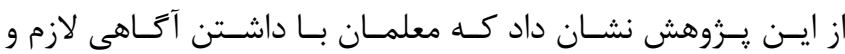

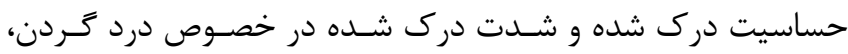
خود كارآمدى كافى جهت انجام رفتارهـاى קيشـخيرى كنـــده از درد كردن را ندارند. بسيارى از معلمان مشكلات مالى، كمبود نيروى كار و حجم زياد كار، و كار كردن در شيفت هاى طولانى رد را عامل ايجـاد

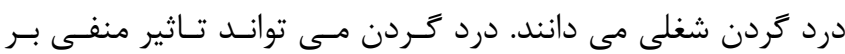

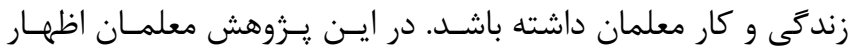
داشتند كه درد گردن مى تواند باعث كاهش كارايى آنـان در انجـام

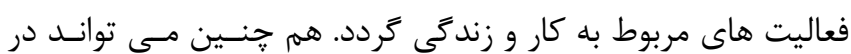


انجام رفتارهاى يِيشَيرى كننده درد كردن و تـامين منـابع انسـانى

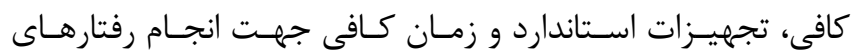

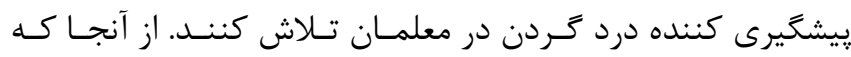

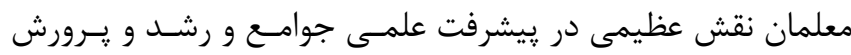

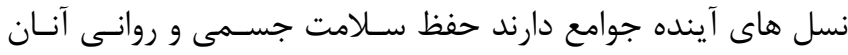

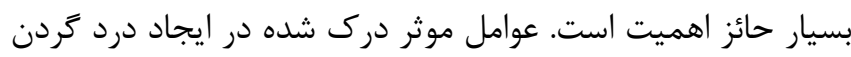

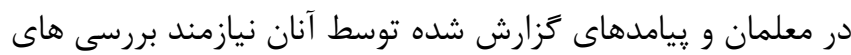

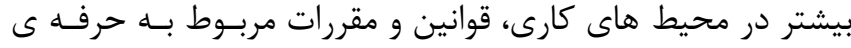

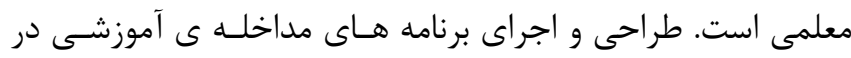

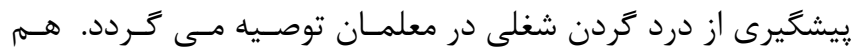

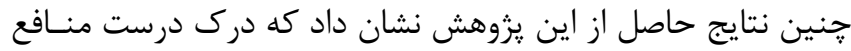

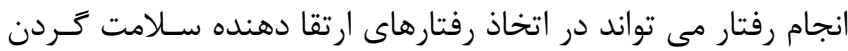
توسط معلمان نقش موثرى داشته باشد.

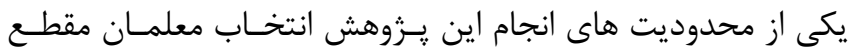
متوسطه اول شهر تهران بود كه ممكن اسـت ديـدكاه آنـان از سـاير

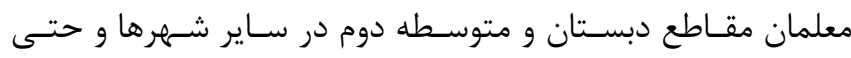

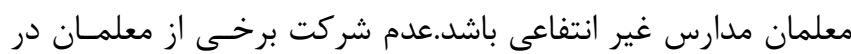

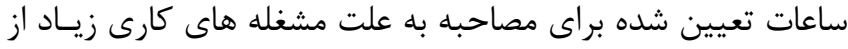

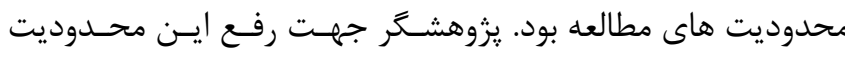

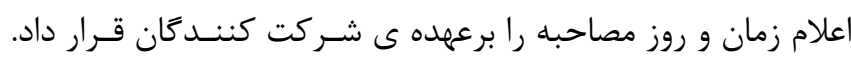

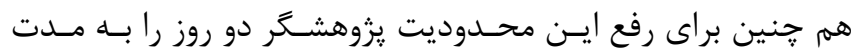

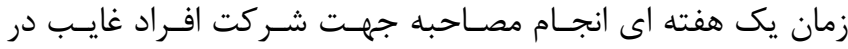

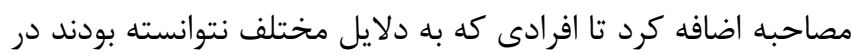
مصاحبه شركت كنند در مدت زمان اضافه شده بتوانند در مصـاحبه

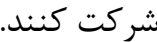

\section{سمه نويسند}

زهره مرادى: يزوهشكَر اصلى، جمع آورى كننده اطلاعات، تجزيـهـ و تحليل داده ها، نمارش مقاله

صديقه سادات طوافيان: نويسنده مسئول سيده سميه كاظمى: مشاور علمى و مشاركت در تدوين مقاله نواسله مسنول

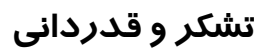

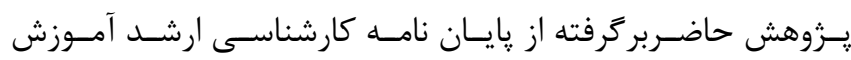

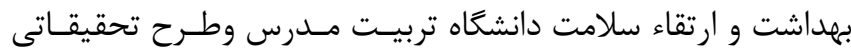
تصويب شده در مركز تحقيقات سلامت دانشكاه تربيت مدرس بـوداء

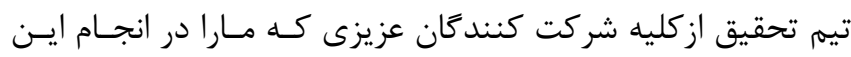
يزروهش يارى كردند صميمانه تشكرو قدردانى مى نمايد.

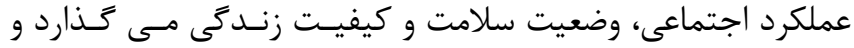
منجر به كاهش كيفيت زندگى، مرخصى و غيبت هاى مكرر، كاهش

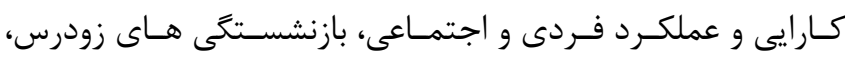
ناتوانى در انجام فعاليت و تحميل هزينه هاى بهداشتى بـائى براى معاى معلمان

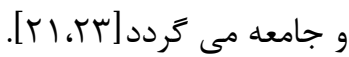

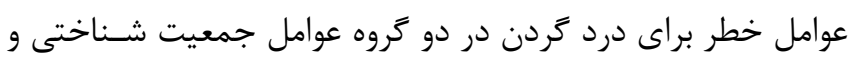

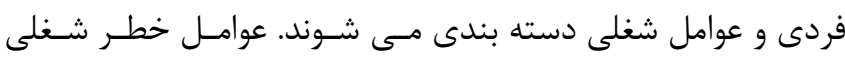

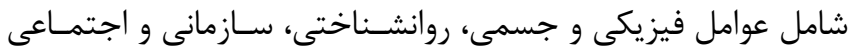

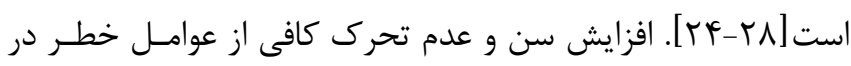

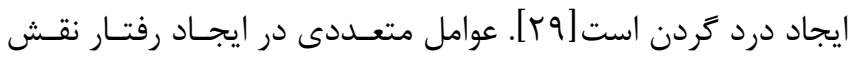

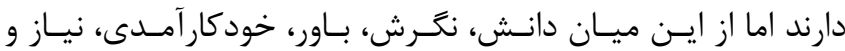

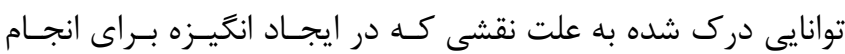

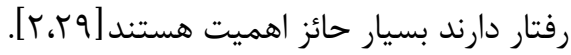

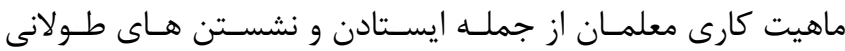

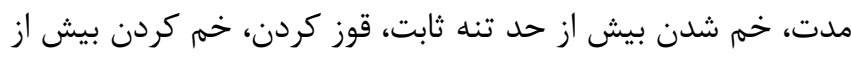

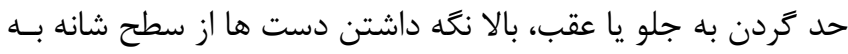

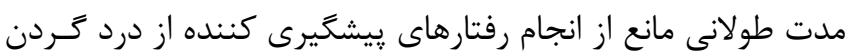

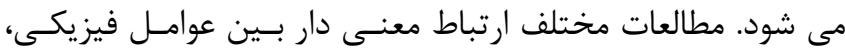

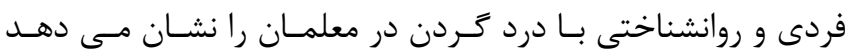

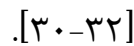

مطالعات بسيارى نشان مى دهد كه عوامل مختلفى از جمله سـاعات

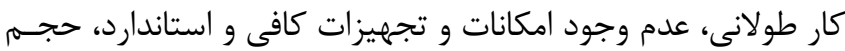

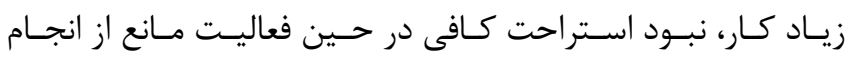

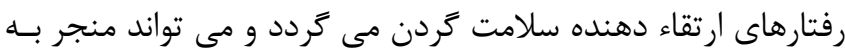

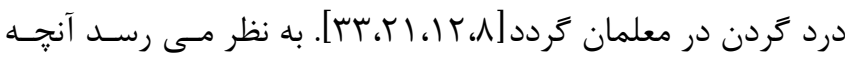

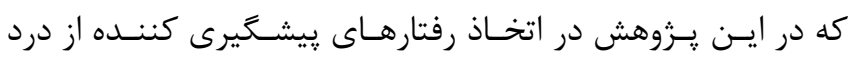
كردن در معلمان موثر واقع كردد شناسايى موانـع موجـود در انجـام رفتار و كاهش و حذف آن ها است. وجود قوانين و مقر رات سـازمانى مردي

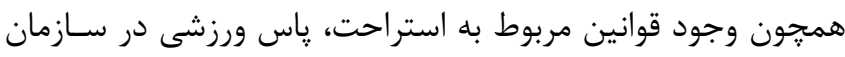

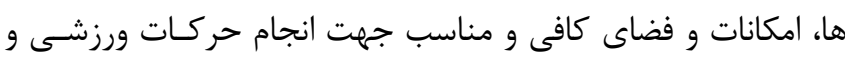
حضور متخصصان ارتقـاى سـلامت مسى توانــد در اتخـاذ رفتارهـاى

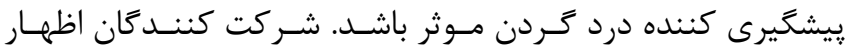

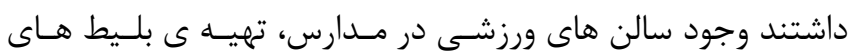

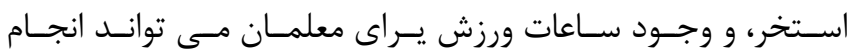

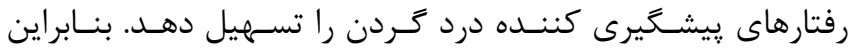

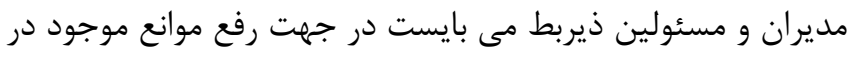




\section{منابع}

1.MM K. Work related musculoskeletal disorders among preparatory school teachers in Egypt. Egyptian Journal of Occupational Medicine 2017;41:115-26

2.Verma R, Madhavi K. The Effect of Postural Education on Decreasing the Severity of Neck Pain in Female School Teachers: A Prospective Cohort Study. International Journal of Therapies and Rehabilitation Research 2017;6:24

3.Jahre H, Grotle M, Smedbråten K, Dunn KM, Øiestad BE. Risk factors for non-specific neck pain in young adults. A systematic review. BMC Musculoskeletal Disorders 2020;21:1-12

4.Damayanti S, Zorem M, Pankaj B. Occurrence of Work Related Musculoskeletal Disorders among School Teachers in Eastern and Northeastern Part of India. International Journal of Musculoskeletal Pain Prevention 2017;2:187-92

5.Norozi E, Malakimoghadam H. Factors affecting arthritis preventive behavior in middle-aged women in Birjand using the Health Belief Model. Journal of Birjand University of Medical Sciences 2018;25:33441 [In Persian]

6.Misailidou V, Malliou P, Beneka A, Karagiannidis A, Godolias G. Assessment of patients with neck pain: a review of definitions, selection criteria, and measurement tools. Journal of Chiropractic Medicine 2010;9:49-59

7. Shuai J, Yue P, Li L, Liu F, Wang S. Assessing the effects of an educational program for the prevention of work-related musculoskeletal disorders among school teachers in China. BMC public health 2014;14:1211

8. Yue P, Liu F, Li L. Neck/shoulder pain and low back pain among school teachers in China, prevalence and risk factors. BMC Public Health 2012;12:1-8

9.Glanz K, Rimer BK, Viswanath K. Health behavior: Theory, research, and practice: John Wiley \& Sons , $5^{\text {th }}$ Edition: San Francisco, 2015

10.Jeihooni AK, Askari A, Kashfi SM, Khiyali Z, Kashfi SH, Safari O, et al. Application of health belief model in prevention of osteoporosis among primary school girl students. International Journal of Pediatrics-Mashhad 2017;5:6017-29 [In Persian]

11.Green J, Thorogood N. Beginning data analysis. Qualitative Methods for Health Research $3^{\text {th }}$ Edition, SAGE Publications Ltd: London, 2013

12. Charoenpol F-n, Tontisirin N, Leerapan B, Seangrung R, Finlayson RJ. Pain experiences and intrapersonal change among patients with chronic non- cancer pain after using a pain diary: a Mixed-methods study. Journal of Pain Research 2019;12:477

13.Elo $S$, Kyngäs $H$. The qualitative content analysis process. Journal of Advanced Nursing 2008;62:107-15 14.Morse JM, Field PA. Qualitative research methods for health professionals 1995[Available from: http://www.sidalc.net/cgi-

bin/wxis.exe/?IsisScript=sibe01.xis\&method]

15.Miles J, Gilbert P. A handbook of research methods for clinical and health psychology: Oxford University Press on Demand, First Edition 2005

16. Graneheim UH, Lundman B. Qualitative content analysis in nursing research: concepts, procedures and measures to achieve trustworthiness. Nurse Education Today 2004;24:105-12

17.Kazemi S-S, Tavafian S-S, Hidarnia A, Montazeri A. Consequences and factors affecting work-related low back pain among nursing professionals: A qualitative study. Payesh (Health Monitor) 2019;18:291-303[In Persian]

18.Hsieh H-F, Shannon SE. Three approaches to qualitative content analysis. Qualitative Health Research 2005;15:1277-88

19.Tullar JM, Brewer S, Amick BC, Irvin E, Mahood Q, Pompeii LA, et al. Occupational safety and health interventions to reduce musculoskeletal symptoms in the health care sector. Journal of Occupational Rehabilitation 199-219:9,20,2010

20.Chaiklieng S, Suggaravetsiri P. Risk factors for repetitive strain injuries among school teachers in Thailand. Work 2012;41:2510-5

21.Ehsani F, Mohseni-Bandpei MA, Fernández-DeLas-Peñas C, Javanshir K. Neck pain in Iranian school teachers: Prevalence and risk factors. Journal of Bodywork and Movement Therapies 2018;22:64-8 [In Persian]

22.Rosenstock IM, Strecher VJ, Becker MH. Social learning theory and the health belief model. Health Education Quarterly1988;15:175

23.Temesgen MH, Belay GJ, Gelaw AY, Janakiraman $B$, Animut Y. Burden of shoulder and/neck pain among school teachers in Ethiopia. BMC Musculoskeletal Disorders 2019;20:1-9

24.Erick PN, Smith DR. Musculoskeletal disorders in the teaching profession: an emerging workplace hazard with significant repercussions for developing countries. Industrial Health 2015;53:385-6

25.Maghsoudian L. Ergonomic assessment of musculoskeletal disorders risk factors in office staff 


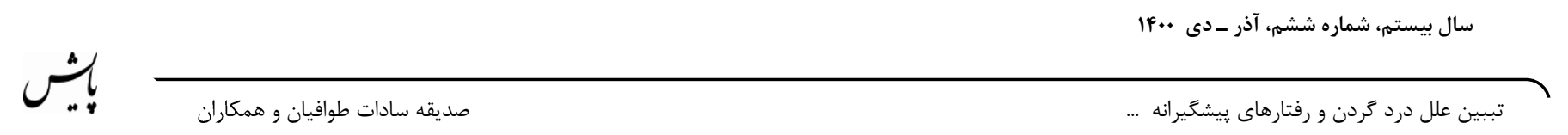

using ROSA method and Its relation with efficiency. Journal of Military Medicine 2017;19:31-9[In Persian] 26. Abe T, Kamada M, Kitayuguchi J, Okada S, Mutoh Y, Uchio Y. Is being a regular player with fewer teammates associated with musculoskeletal pain in youth team sports? A cross-sectional study. BMC Musculoskeletal Disorders 2017;18:105

27.Anuar NFM, Rasdi I, Saliluddin SM, Abidin EZ. Work task and job satisfaction predicting low back pain among secondary school teachers in Putrajaya. Iranian Journal of Public Health 2016;45:85-92

28.Lanhers C, Pereira B, Garde G, Maublant C, Dutheil F, Coudeyre E. Evaluation of a digital preventive tool for musculoskeletal disorders in computer workers-a pilot cluster randomised trial. BMJ Open 2016;6:1-15

29. Solis-Soto MT, Schön A, Solis-Soto A, Parra M, Radon K. Prevalence of musculoskeletal disorders among school teachers from urban and rural areas in Chuquisaca, Bolivia: a cross-sectional study. BMC Musculoskeletal Disorders 2017;18:425
30.Erick PN, Smith DR .A systematic review of musculoskeletal disorders among school teachers. BMC Musculoskeletal Disorders 2011;12:260

31.Erick P, Smith D. Musculoskeletal disorder risk factors in the teaching profession: a Critical review, Newcastle, Ourimbah, Australia. OA Musculoskelet Med 2013

32.Cheng H-YK, Wong M-T, Yu Y-C, Ju Y-Y. Workrelated musculoskeletal disorders and ergonomic risk factors in special education teachers and teacher's aides. BMC Public Health 2016;16:137

33.Llewellyn C, Ayers S, McManus C, Newman SP, Petrie K, Revenson T, et al. Cambridge handbook of psychology, health and medicine: Cambridge University Press, $1^{\text {st }}$ Edition: UK, 2019 